\title{
AZ IKT HATÁSA A KOGNITÍV MÜKÖDÉSEKRE ISKOLÁSKORBAN
}

\author{
DÁVID MÁRIA ${ }^{1}$ - DORNER LÁSZLÓ ${ }^{1}$ - HATVANI ANDREA ${ }^{1}$ - \\ SOLTÉSZ PÉTER ${ }^{1,2}-$ TASKÓ TÜNDE ${ }^{1}-$ \\ SOLTÉSZ-VÁRHELYI KLÁRA ${ }^{1,2}$ \\ ${ }^{1}$ Eszterházy Károly Főiskola Pszichológia Tanszék \\ ${ }^{2}$ Pázmány Péter Katolikus Egyetem Általános Lélektani Tanszék \\ e-mail: davidm@ektf.hu; dorner@ektf.hu; hatvani@ektf.hu; petsol@ektf.hu; \\ taskot@ektf.hu; soltesz-varhelyi.klara@btk.ppke.hu
}

Beérkezett: 2015. szeptember 15. - Elfogadva: 2015. november 15.

\begin{abstract}
Háttér és célok: Tanulmányunkban arra kerestük a választ, hogy hogyan változnak a 10-18 éves korosztály képességei, készségei az új infokommunikációs technológiák (IKT) elterjedésével. Feltételezésünk szerint a gyakori IKT-használat bizonyos készségek javulását (például vizuális észlelési képességek), míg más készségek romlását (például verbális és motorikus) eredményezi.

Módszer és minta: 2014 februárjával bezárólag keresztmetszeti vizsgálatot végeztünk három korosztály bevonásával, 492 fös mintán (194 fö 10 éves; 166 fö 14 éves és 132 fö 18 éves). Mindegyik korcsportban alacsony, közepes és magas IKT-használati alcsoportokat különböztettünk meg. Az általunk adaptált online pszichológiai teszteket végeztük el a tanulókkal az alapvetö kognitív képességeik vizsgálatára, valamint egyéni adatfelvétele alapuló verbális feladatokat. Ezen kívül a különbözö korcsoportokhoz tartozó tanulók kompetenciaméréseinek (szövegértés, matematikai-logikai) és a Hungarofit (alapvető motorikus képességek és állapot) vizsgálati eredményeinek és a tanulmányi eredményeinek összehasonlitó elemzése is megtörtént. A vizsgálat egri és Eger környéki általános és középiskolákban zajlott. A nemek aránya a mintában kiegyensúlyozottnak tekinthetö (205 fiú és 287 lány).

Eredmények: A gyakoribb számítógép-használat és a reakcióido" pozitív összefüggést mutat minden korcsoportban. A mérsékelt IKT-használat a legtöbb kognitív funkcióval pozitív együttjárást mutat. A matematika és szövegértés kompetenciában nem volt eltérés a három csoport között, ahogyan a Hungarofit mérésekben sem. A magyar nyelv és irodalom, idegen nyelv, matematika tanulmányi eredmény és az összesitett tanulmányi átlag tekintetében sem mutatkozott szignifikáns különbség a különbözö csoportok között.
\end{abstract}


Következtetések: A mérsékelt számítógép-használat hatása a kognitív készségekre enyhén pozitív, de ez az iskolai eredményesség mutatókban és kompetenciaadatokban, valamint a mozgásos eredményekben nem manifesztálódik.

Kulcsszavak: IKT, kognitív képességek, Hungarofit, kompetenciamérések

Életünk megkerülhetetlen részévé vált az Internet és az infokommunikációs (IKT) eszközök használata. Időről időre heves viták bontakoznak ki azzal kapcsolatban, hogy az eszközök használata inkább pozitív vagy negatív hatással bír a felhasználó szempontjából. Nemrégiben jelent meg az OECD éves jelentése, melyben azt a vizsgálati eredményt közölték, miszerint azoknak az oktatási rendszereknek a diákjai, amelyek sokat áldoznak az információs és kommunikációs technológiákra, „nem mutatnak észrevehető fejlődést” az olvasás, a matematika, illetve a tudományok terén, vagyis önmagában ezen eszközök iskolai jelenléte és rendszeres felhasználása oktatási célokra nem garancia a tanulmányi eredményesség és a tanuláshoz szükséges kompetenciák fejlődésére. Ugyanezen jelentés viszont azt is kiemelte, hogy a számítógépet mérsékelten - heti egy vagy két alkalommal - használó diákok „valamivel jobban teljesítenek” a többieknél. Ez a kérdésfelvetés egybevág kutatásunk alapkérdésével, hogy milyen összefüggést találunk az iskolai és otthoni IKT-használat gyakorisága, illetve a különböző kognitív képességek és a kompetenciamérés eredményei között (OECD, 2015).

\section{Az IKT-használat pszichés funkciókra gyakorolt hatása}

A változások különösen az új generációk - Prensky (2001) szóhasználatával élve a digitális bennszülöttek - pszichés és motoros képességeire hatnak erőteljesen, hiszen ők már egy olyan társadalomba „nőnek bele”, ahol ezeknek az eszközöknek a mindennapi használata természetes, szemben a digitális bevándorló szüleikkel, nagyszüleikkel, akik az új információkeresési, -előállítási és -feldolgozási módokhoz - részben a szokásrendszerük, jól működő sémáik okán is - nehezen alkalmazkodnak.

Prensky (2001) szerint ez együtt jár azzal, hogy a digitális bennszülöttek gondolkodása eltér az idősebbekétől, másként dolgozzák fel a külvilágból származó információkat. Idézi Bruce D. Berryt a Baylor College of Medicine professzorát, aki szerint „Az eltérő tapasztalatok eltérő agyi felépítést eredményeznek”. A digitális bennszülötteket a generációelméletek szerint az 1995-96 után született Z generációval azonosíthatjuk. Tari Annamária (2011) a Z generáción belül is megkülönböztet első és második hullámot. Az első hullám nemzedékét a 1995-2005 között születettek alkotják. Ez a hullám a fokozott Internet- és közösségioldal-használat kezdetekor már felhasználó volt, rugalmas, jól ért az IKT-eszközök technikájához, legalábbis felhasználói szinten. A második hullámba tartoznak a 2005-2010 között születettek, ők már beleszülettek abba a korba, ahol a közösségi oldalon ott kell 
lenni, és ahol az érintőképernyős készülékek, a multitasking és az on-demand szórakozás (videó- és hanganyagokat, filmeket lehet egy központi szolgáltatásból letölteni, igény szerinti időben) természetes.

Az előzőekből következik, hogy az IKT fejlődése a tanulási-tanítási folyamatra is nagy hatással van, ugyanakkor e technológiai fejlődés tanulási és tanítási folyamatot átalakító erejére jelen pillanatban kevés empirikus bizonyíték áll még rendelkezésre (Molnár, 2011). Hasonlóképpen kevéssé kutatott az infokommunikációs technológia fejlődésének kognitív és motoros képességekre gyakorolt hatása. Fontos kérdés ugyanakkor az is, milyen attitűdökkel rendelkeznek a diákok az infokommunikációs eszközökkel kapcsolatban. Egy finn kutatócsoport (Hakkarainen és mtsai, 2000) például 550 finn általános és középiskolás diák IKT-eszközhasználati kompetenciáit és gyakorlatát vizsgálva, 3 fö faktort emeltek ki: Az első faktor a tanulók azon meggyőződéseit mutatja, hogy az IKT-eszközökkel támogatott tanulás bátoríthatja az egyént, hogy több erőfeszítést fektessen a tanulásba, melyet ugyanakkor ezen eszközök használata gyakran élvezetesebbé és hatékonyabbá is tesz. A második faktor az otthoni IKT-használat gyakoriságát, az IKT-használati kompetencia a tanuló által észlelt önbevallásos értékét és ez irányú tapasztalatait, más személyeknél történő átadási hajlandóságát tartalmazta, míg a harmadik az iskolai IKT-használat intenzitását jelölte, amit erősebben bejósolt az IKT-eszközök iskolai elérhetősége, mint a tanuló IKT-kompetenciái.

\section{Az IKT-használat hatása a kognitív képességekre}

Nagy József (2000) tudásszerző képességek néven illeti azt a képességcsoportot, amely az információfelvétellel, illetve feltárással hoz létre új tudást. Az ismeretszerző, az alkotó és a problémamegoldó képesség hármasát sorolja ebbe a kategóriába. Az ismeretszerző képességet úgy tekinti mint „sajátos funkciójú önálló képességet, melynek köszönhetően az információk szándéktalan felvétele mellett a szükséges ismeretek szándékos megkeresését, kiválasztását, felvételét is el tudjuk végezni” (Nagy, 2000, 115).

A különböző kutatások eredményeire alapozva megállapíthatjuk, hogy az IKThasználat a helyzettől, a használat mennyiségétől és minőségétől, az életkori jellemzőktől függően pozitív és negatív hatással egyaránt lehet a különböző kognitív képességekre.

Subrahmanyam, Greenfield és Kraut (2001) például a kognitív képességekre gyakorolt pozitív hatásról számoltak be, különös tekintettel az intelligenciára és az iskolai eredményességre. Samari és Attashak (2011) az IKT-technológiák alkalmazásának iskolai eredményességet fokozó hatását említik. Vizsgálatuk alapján ugyanis pozitív hatása van az önszabályozó tanulás kialakulására és a tanulással kapcsolatos önbecsülésre, a (tanártól) független aktív tanulás használata révén (az így tanuló diákok mindig új forrásokat és információkat keresnek). Sharifi, Imani és Eslamieh (2012) terepkutatása rávilágít az IKT-eszközök használatának a tanulók kollaboratív tanulására gyakorolt pozitív hatására. Vebra (2002) szerint az IKT-eszközökkel segített tanulás gyorsabb információfeldolgozáshoz vezet, ezáltal 
7növeli a tanulás hatékonyságát és a kognitív feldolgozás szintjét. Ugyancsak az IKT-használat pozitív hatása, hogy az IKT-eszközök használata bizonyos tanulóknál jobb kommunikációs és önszabályozási képességhez vezet (Fallahi, 2011). Subrahmanyam és munkatársai (2001) vizsgálataiból kiderül, hogy bizonyos számítógépes játékok specifikus fejlesztő hatást gyakorolnak egyes kognitív képességekre. Minden vizsgálat kiemeli a használat mennyiségét, mint fontos közvetítő változót, számos esetben azt tapasztalhatjuk, hogy a felszínes, leggyakrabban unaloműző használat mennyisége negatív összefüggést mutat a kognitív képességekre gyakorolt pozitív hatással, ellenben a mélyre hatoló, információkereső vagy valamely tudáselem (például nyelvi szókincs) fejlesztésére irányuló IKT-aktivitás és a megszerzett információk szisztematikusabb feldolgozása, szintetizálása ezen képességek fejlődéséhez járulhat hozzá. A kommunikációs célú IKT-használat gyakorisága összefüggésben áll az erőfeszítést igénylő gondolkodás preferenciájával, a megismerésre irányuló igénnyel. Így elmondhatjuk, hogy a magas szintủ megismerési igénnyel bíró emberek belső motivációt éreznek az új tudáselemek keresésére és az intellektuálisan kihívást jelentő, mélyebb gondolkodásra, szívesen köteleződnek el az internetes keresésben és az új tartalmak integrálásában, valamint az információkat gondosabban is dolgozzák fel (Cacioppo és Petty, 1982; Zhong, Hardin és Sun, 2011).

Az eddigi vizsgálatok szerint a számítógépek bizonyítottan javítják a vizuális intelligencia képességeit, mint például a térbeli tájékozódást és orientációt, az ikonikus (képi reprezentációs) képességeket és a vizuális figyelmi képességeket. Ez azért lehetséges, mert sokkal inkább vizuális, mintsem verbális információfeldolgozást követelnek a használóiktól (Subrahmanyam és mtsai, 2001).

Egyes kutatók, mint például Patricia Greenfield (1998), a Flynn-hatás (az IQtesztekben javuló teljesítmény az USA-ban) mögött is az IKT-eszközök fejlesztő hatását feltételezik. Greenfield és munkatársai szerint a számítógépes technológia tartósan befolyásolja a téri-vizuális képességeket, mivel a számítógépes alkalmazások többsége verbális helyett vizuális információfeldolgozást igényel. Ez magyarázhatja a verbális IQ lassabb növekedését (Kovács, 2007).

Maynard, Subrahmanyam és Greenfield (2005) szerint a számítógépes játékok háromféle módon gyakorolhatnak hatást a megismerésre:

- Javítják a megosztott vizuális figyelmet és a párhuzamos vizuális feldolgozást.

- Javítják a mentális transzformációt.

- A hangsúly eltolódik a verbális reprezentációkról a téri és ikonikus reprezentációkra (Kovács, 2007).

Negatív hatás viszont, hogy az IKT-eszközök gyakori használata a kritikai gondolkodás csökkenését okozhatja, hiszen az állandó információáradat nem ad lehetőséget a precizitásra és a mélyebb kognitív feldolgozásra. Az internethasználat, különösen a Google és más hasonló keresőprogramok alkalmazása megváltoztatja az emlékezeti teljesítményt, mivel az ennek használatához szokott felhasználó nem az információt, hanem az információ elérési útját igyekszik megjegyezni (Tari, 2011). Greenfield (2009) szerint a figyelem időtartalmának rövidülése és a képekben való gondolkodás erősödése jellemzi az elvont gondolkodással szemben. 
Bavelier és munkatársai (2012) szerint a videojátékok javítják a vizuális figyelmet, de ez azzal jár együtt, hogy a valós élethez jobban közelítő, vizuálisan ingerszegényebb környezetben a figyelem könnyebben elterelhető. Greenfield (2009) azt is kiemeli, hogy a képek, a készen kapott ikonok a szimbolikus gondolkodás fejlődése ellen hatnak, emellett az alábbi magasabb rendű kognitív folyamatokra és funkciókra is negatív hatást gyakorolhat: absztrakt szókincs, reflexió, induktív problémamegoldás, kritikai gondolkodás, absztrakcióra való képesség, képzeleti tevékenység. Míg korábban az új információ szerzése például egy könyv elolvasása révén lineáris folyamat volt, most honlapról honlapra „ugrálva” történik a keresés, ami az asszociatív gondolkodásnak kedvez, viszont nehezíti az új információ elmélyült bevésését és feldolgozását (Tari, 2011). Prensky (2001) azt emeli ki, hogy a digitális bennszülöttek hozzászoknak ahhoz, hogy nagyon gyorsan jutnak új információkhoz, hajlamosak párhuzamos feldolgozásra, egyszerre több dologgal foglalkoznak (multitasking), ami szintén felszínes információfeldolgozást eredményezhet. Jobban kedvelik az a vizuális információt, az ábrákat és a képeket, mint a szöveges információt.

\section{Az IKT-használat egészségügyi állapottal kapcsolatos összefüggései}

A Z generáció tagjaira az alvásidő lerövidülése, gyakran krónikus kialvatlanság jellemző (Tari, 2011). A kialvatlanság a verbális kreativitás, a problémamegoldás és az absztrakt gondolkodás képességeinek hanyatlásához vezethet (Pilcher és Walters, 1997). A késői órákban, lefekvés előtt végzett IKT-aktivitások olyan mértékben megnövelik az agyi arousal-szintet és az éberséget, hogy a személy később tud elaludni, így a normál alvási ciklusa felborul, aminek következtében fáradtabban ébred, ennek pedig számos negatív egészségügyi következménye lehet. Ronthatja a figyelmi funkciókat és az érzelemszabályozást, negatív hatást gyakorolhat a hormonháztartásra és az anyagcsere-funkciókra (Spear, 2000; Mannir és mtsai, 1997; Dahl, 1996, 1998; Spiegel, Leprould és Van Cauter, 1999; Bonnet, Berry és Arand, 1991). A gyakori IKT-használat összefüggésben állhat az izom- és csontrendszer problémáival, hiszen a személy gyakran hosszabb időn át statikus pozíciókban marad, különösen gyakran számolnak be a nyak-váll, illetve a hát alsó részének fájdalmáról, valamint a túlsúllyal is szignifikáns összefüggést mutat az IKThasználat gyakorisága (Alexander és Currie, 2004; Jacobs és Baker, 2002; Hakala és mtsai, 2006; Kautiainen és mtsai, 2005).

A kutatók ugyancsak leírják, hogy az Internet számos serdülő számára oly mértékben addiktív lehet, hogy megnő a kockázata annak, hogy elveszítik a kontrollt viselkedésük felett (Eppright, Allwood, Stern és Theiss, 1999; Kaltiala-Heino, Lintonen és Rimpela, 2004). A számítógéptől való függősség a viselkedéses addikciók közé tartozik. Különösen azok veszélyeztetettek, akik hajlamosak a szociálisan inaktív életmódra, és akiknek alacsony az önértékelése (Demetrovics és Koronczai, 2010). Nem egységes a szakma megítélése abban, hogy az internetfüggőség külön betegségként vagy csupán egy másik pszichés probléma lecsapódási felületeként kezelendő (Boronkai, 2011). Szabó Éva (2014) a kérdéskör elemzésekor egy fon- 
tos szempontra világít rá, mely az addikciók magas előfordulási rátáit magyarázhatja: neuropszichológusok jelentős csoportja állítja ugyanis, hogy a problémás internethasználat hatására kialakulható függőség élménye a flow-élményhez hasonlatos, vagyis ahhoz, amikor az ember úgy belemerül valamibe, hogy elfeledkezik minden másról. Ez a flow-élmény akár egy online játékban is megélhető, és függőségélményt okozhat. Ebből a szempontból a használat mennyisége és minősége is fontos szempontnak tekinthető. Tamir és Mitchell (2012) szerint bizonyos médiahasználati viselkedések (például közösségi oldalakon történő tartalommegosztás, játék) a droghasználat vagy a szex esetén aktiválódó agyterületek stimulációjához járulnak hozzá. Ez az önfeltárás által az intrinzikus jutalmazó rendszerünk fokozott aktivitásával is együtt jár.

\section{VIZSGÁLATI KÉRDÉSEINK}

Kutatásunk során arra kerestük a választ, hogy az új tudáshordozók használatával hogyan változnak a kognitív teljesítmények és a tanulói képességek a 10-18 éves korosztály körében. Célunk a számítógép-használat (IKT-használat) és a kognitív képességek összefüggéseinek feltárása, az infokommunikációs technológiákat gyakran és ritkán használó gyerekek csoportjainak összehasonlítása.

Mivel feltételezzük, hogy a gyakori IKT-használat hatással van a különböző készségekre, így arra keressük a választ, hogy az IKT-eszközöket „sokat” és a „keveset” használók csoportjai között milyen különbségek vannak a különböző készségeket mérő feladatoknál, a tanulmányi eredményben, a Hungarofit vizsgálatban és a kompetenciaméréseken (utóbbi háromról szintén azt feltételeztük, hogy a készségeket tükrözik). Kutatásunk során az alábbi hipotéziseket vizsgáltuk:

1. A XXI. század fiataljainak képességei megváltoznak az infokommunikációs technológiák használata következtében, az IKT-eszközök használati gyakorisága függvényében a kognitív mutatók között különbségeket feltételezünk. Feltételeztük, hogy a gyakori IKT-használat bizonyos készségek javulását (például vizuális észlelési képességek) eredményezi.

2. Más készségek romlását (például motorikus, verbális képességek) vártuk.

3. Feltételeztük, hogy a képességbeli különbségek a tanulmányi teljesítményekben is megmutatkoznak.

\section{MÓDSZER}

Egy tesztbattériát alakítottunk ki, amely három feladattípust tartalmazott:

1. online pszichológiai próbák;

2. verbális próbák, egyéni adatfelvétellel;

3. az országos kompetenciamérési adatok és a tanulmányi eredmények dokumentumelemzése. 
1. Online pszichológiai próbák: ${ }^{1}$

Az alapvető kognitív képességek vizsgálatára grafikus teljesítményteszteket használtunk. Ezek végrehajtása személyenként kb. 45 percet vett igénybe. Az online pszichológiai próbák a következő képességterületeket mérik:

- Reakcióidő - A személyek reakcióidejét mérő feladat. A feladat során a kísérleti személynek gyorsan felvillanó vizuális ingerekre kellett minél rövidebb idő alatt egérkattintással reagálni. A teszt összesen 20 itemből áll, melyek a válaszadás után 2-4 másodpercenként (2 plusz egy 0 és 2 másodperc közötti véletlenszerű késleltetéssel) jelennek meg. Amennyiben nem érkezett válasz az inger 1 másodperc után eltűnt, és a következő inger a már ismertetett várakozással megjelent, ugyanakkor a 0,7 másodperc feletti értékeket a mutatók számításánál már kihagyásnak tekintettük.

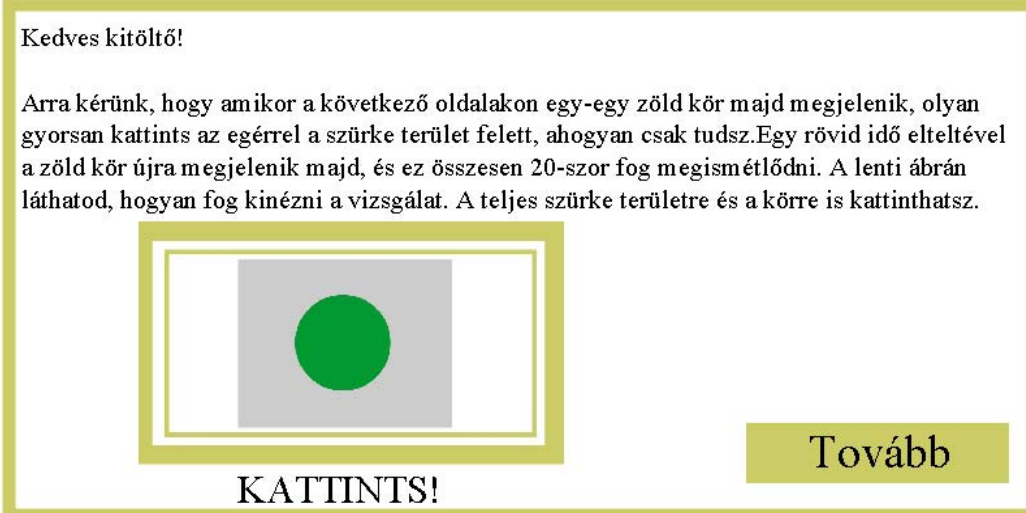

1. ábra. Egyszerű reakcióidő-feladat

- Go-NoGo - Szelektív reakcióidő mérő feladat, a személyek gátlófunkcióit méri. A feladat során a kísérleti személynek az egyikféle vizuális ingerre gyorsan egérkattintással kellett reagálni, míg a másik - egyébként hasonló ingert - válasz nélkül kellett hagynia. Összesen 20 inger jelent meg a próba során, amelyek meghatározott sorrenden követték egymást. A 20 ingerből 8 (40\%) volt „no-go” inger, amelyek 1 másodpercig maradtak a helyes kihagyás (helyes elutasítás) esetén fenn a képernyőn. Kihagyás esetén az inger 1 másodperc után eltűnt, és a következő inger egy, a reakcióidőnél már bemutatott 2 és 3 másodperc közötti késleltetéssel érkezett.

${ }^{1}$ A feladatok a http://www.tesztekaneten.com/ektfpsy oldalon elérhetőek a szerzőkkel való egyeztetés alapján, mivel a tesztek csak előre kiadott azonosítókkal érhetőek el. 


\section{Kedves kitöltö!}

Arra kérünk, hogy a zöld kör feltűnésekor olyan gyorsan kattints ahogyan csak tudsz, viszont ha a pöttyös zöld kör jelenik meg, akkor várd meg míg eltünik. Összesen 20 -szor fognak megjelenni körök. A lenti ábrán láthatod, hogyan fog kinézni a vizsgálat sima és pöttyös zöld kör esetén. A teljes szürke terültere és a körre is kattinthatsz!

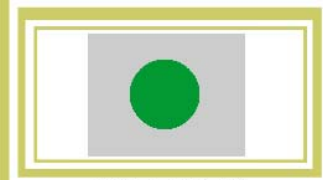

KATTINTS!

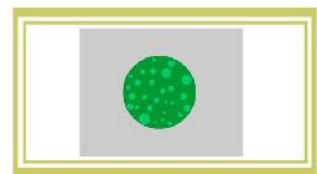

NE KATTINTS!

\section{Tovább}

2. ábra. A Go-NoGo feladat

- Számterjedelem - A személyek rövid távú verbális memóriakapacitását (fonológiai hurok) mérő feladat. Ebben a feladatban a képernyőn felvillanó számsorokat kellett ugyanabban a sorrendben begépelnie a kísérleti személyeknek. A számsorok számjegyenként szeriálisan megjelenítve kerültek bemutatásra, minden számjegy 1 másodpercig volt látható. A számsorok pszeudóvéletlenszerủen generálódtak, azzal a kritériummal, hogy két egyforma számjegy nem követhette egymást. A legkisebb számsor 4 elemủ volt, és minden helyes válasszal eggyel nőtt, minden helytelen válasszal eggyel csökkent a hossza. Három hibát követően a vizsgálat befejeződött, és a személy leghosszabb helyes válaszát mértük.

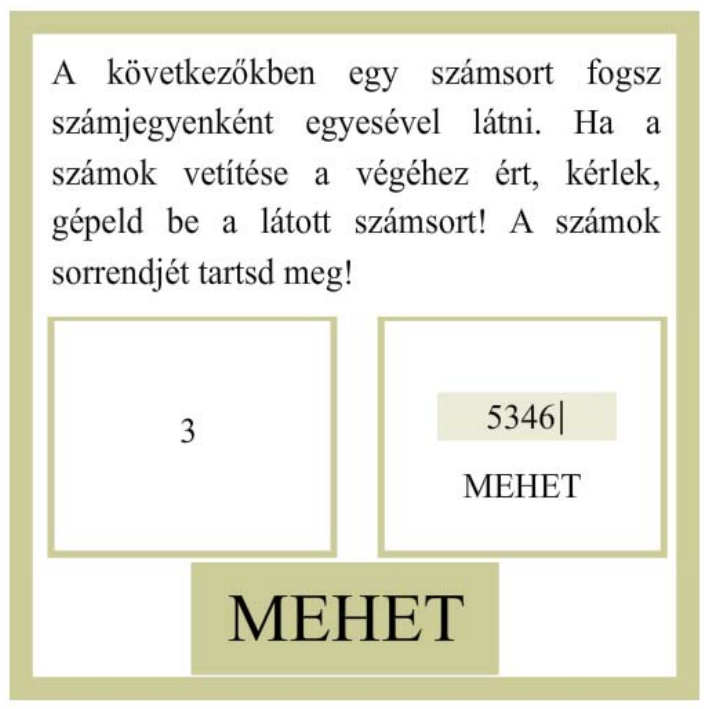

3. ábra. Számterjedelem-feladat 
- Téri memória - A személyek rövid távú téri-vizuális memóriakapacitását (térivizuális vázlattömb) mérő feladat. Ebben a feladatban a kísérleti személyeknek a felvillanó térbeli ingerek helyére kellett emlékezni. A kísérlet egy $4 \times 4$ es táblát tartalmaz, melynek adott számú mezője egyszerre felvillan, majd a személynek a korábban felvillanó négyzeteket kell megjelölnie. A felvillanó négyzetek száma 3-tól kezdődik, és minden helyes válasz esetén eggyel nő, minden helytelen válasz esetén eggyel csökken. Három helytelen válasz után a feladat befejeződik. A vizsgálatban a személyek leghosszabb helyes válaszát mérjük.

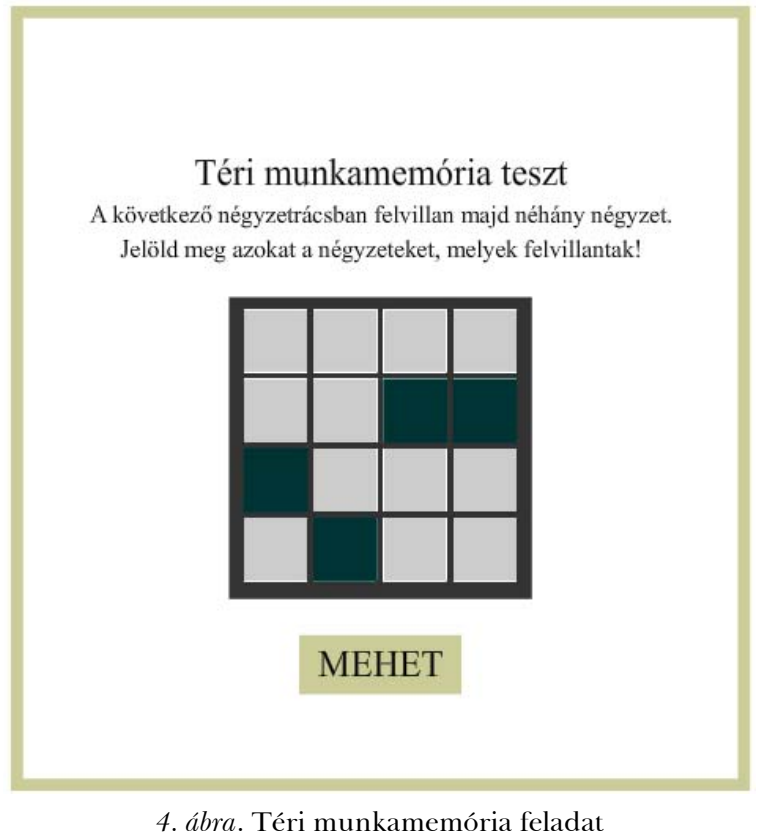

- Téri forgatás - A személyek rövid távú téri-vizuális memóriakapacitását (térivizuális vázlattömb) mérő feladat. A feladatban a kísérleti személyeknek térben elforgatott ábrákról kellett minél gyorsabban megállapítaniuk, hogy azok azonosak-e. Ingerként két $\mathrm{R}$ betűt jelenítettünk meg. A két $\mathrm{R}$ betủ bármelyike lehetett egyenes állásúan vagy tükörképesen megjelenítve. Mindkét R betűt egymástól függetlenül forgattuk 0, 60, 120, 180, 240 és 300 fokkal, így összesen 144 inger került bemutatásra. A személyeknek azt kellett eldönteniük, hogy a két inger megegyezik-e egymással (mindkettő egyenes állású vagy mindkettő tükörkép), vagy nem egyezik meg egymással (az egyik egyenes, a másik fordított állású). 
A következő feladatban arra kérlek, hogy döntsd el, hogy a két körben megjelenö, különbözö szögekben elforgatott $\mathrm{R}$ betü azonos ( $\mathbf{R} \mathbf{R}$ vagy $\boldsymbol{Я} \boldsymbol{Я}$ ), vagy eltérő ( $\boldsymbol{Я R}$ vagy $\mathbf{R} \boldsymbol{Я}$ ) állású. Ha azonos állású, kattints a pipára, ha eltérö, kattints az X-re!

Dönts minél gyorsabban, de törekedj a pontosságra!

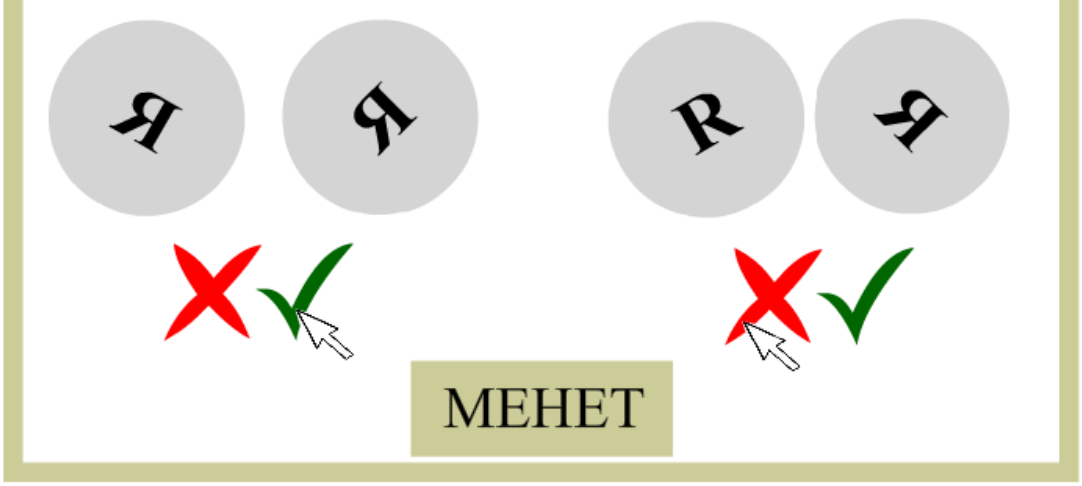

5. ábra. Téri forgatás feladat

- Egyszerüsített Stroop - A személyek gátlófunkcióit mérő feladat. A kísérleti személynek két színnel írt színneveknél kellett a szavak színére minél gyorsabban reagálniuk, miközben figyelmen kívül hagyták az adott szó jelentését. A kísérletben megjelenhetett a KÉK és PIROS színnév kékkel vagy pirossal írva, és a kísérleti személyeknek a betűszínnek megfelelően kellett a KÉK és PIROS nyomógombok közül választani. A személyektől azt kértük, hogy egy perc alatt oldjanak meg minél többet a feladatból. A kísérletben mértük, hogy a személy hány feladatot oldott meg, mekkora a helyes válaszainak aránya, valamint reakcióideje. Ez utóbbi kettőt külön lehet kongruens (szín és szöveg megegyezik) és inkongruens (szín és szöveg különbözik) esetekre számolni. 
A következőben minden alkalommal látsz majd felül egy szót. A Te feladatod eldönteni, hogy ez a szó milyen színú, és az alul megjelö két gomb közül megnyomni azt, amely azt a színnevet tartalmazza, amivel a felső felirat írva van.

Például, ha felül a "KÉK" szöveg pirossal van irva, és alul van egy gomb, amire "PIROS" van írva és egy olyan, amire "KÉK", neked a "PIROS"-at kell megnyomnod! Oldj meg minél többet egy perc alatt!

\section{KÉK}

KÉK

\section{PIROS}

\section{MEHET}
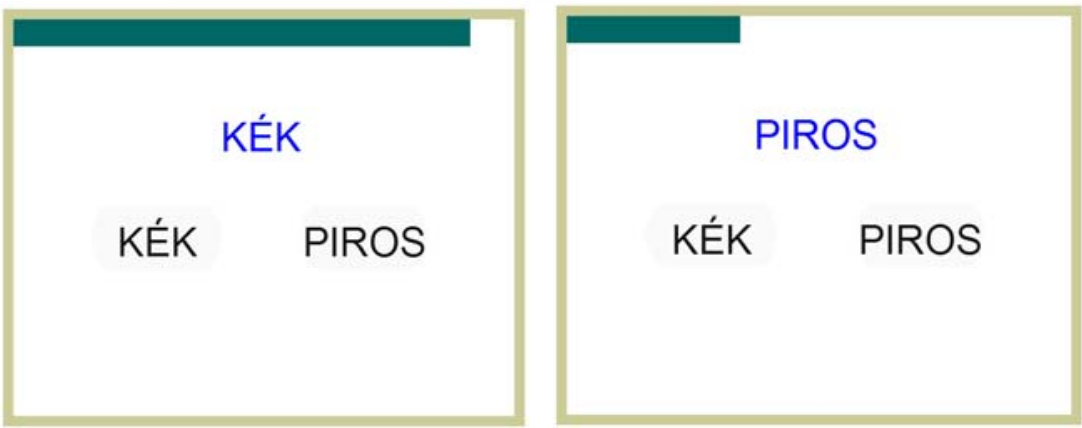

6. ábra. Egyszerűsített Stroop-feladat. Példa kongruens és inkongruens betűszínés színnévpárosításra

- Szempontváltás - A feladatváltás (shift) mint kognitív funkciót mérő feladat. Ebben a feladatban a kísérleti személynek két típusú egyszerű döntési feladatot kellett random váltakozva minél rövidebb idő alatt megoldania. A kísérletben megjelent a képernyőn egy jelzőinger, mely lehetett „SZÁM” vagy „BETÜ”, mely arról instruálta a kísérleti személyt, hogy a jelzőinger alatt megjelenő betű-szám párból a betűről vagy számról kell döntést hoznia. Betűk esetén azt kellett eldönteni, hogy mással- vagy magánhangzó-e, számok esetén, hogy páros vagy páratlan. A vizsgálatban összesen 64 mérés történt, ahol a betű-szám párok és az, hogy a betűre vagy a számra kell reagálni, véletlenszerűen voltak kiválasztva. A vizsgálatban mértük a személyek helyes válaszainak arányát és reakcióidejüket, melyből mutatók számolhatók azokra az esetekre, ahogy nem kellett az előző feladathoz képest szempontot váltani (SZÁM-ot SZÁM vagy BETÜ-t BETÜ követett), és azokra az esetekre, ahol szempontváltásra volt szükség (SZÁM-ot BETÜ vagy BETÜ-t SZÁM követett). 


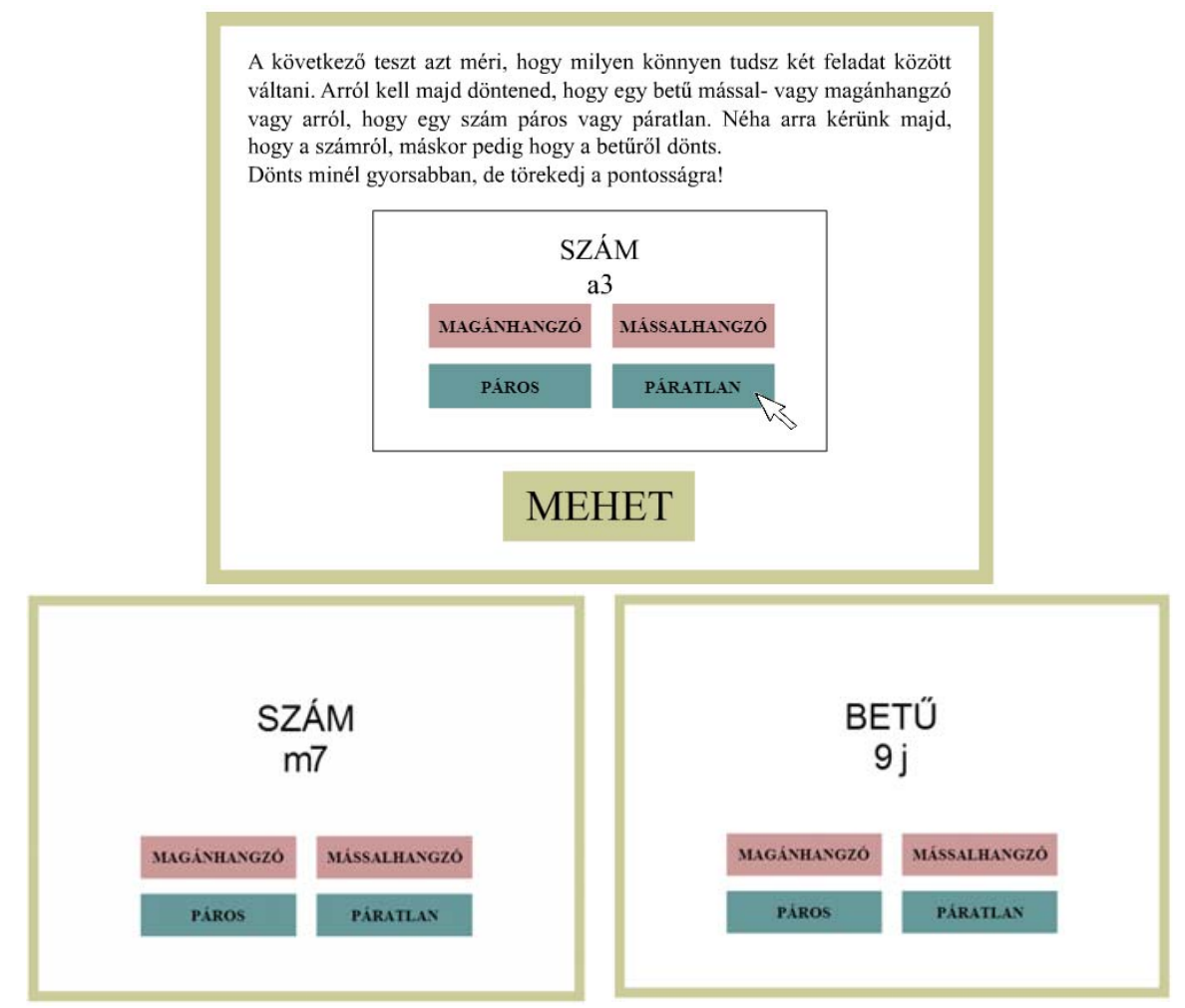

7. ábra. Szempontváltás feladat. Egy példa a szempontváltásra, míg az első ábrán a számnak megfelelően a páratlanra kell kattintani, addig a másodikon már a betűnek megfelelően a mássalhangzóra

- Logikai gondolkodás - Összetett kognitív képességeket mérő feladat, melyben van egy téri viszony komponens és egy logikai értékelő mozzanat. A kísérleti személyeknek relációelemző feladatokat kellett minél gyorsabban megoldaniuk. A feladat kétfajta vizuális ingert tartalmazott az ábrán látható módon: egy nagyobb négyzetben egy kisebb kört vagy egy nagyobb körben egy kisebb négyzetet. A vizuális inger fölött jelent meg a relációs kijelentés, melynek helyességéről kellett a személyeknek dönteni. A kijelentéshez a következő relációs viszonyt jelző állítmányokat használtuk: „kisebb”, „nagyobb”, „benne van”, „tartalmazza” és „magában foglalja”. A relációs kijelentések fele állító, fele tagadó volt („A kör kisebb a négyzetnél” és „A kör nem kisebb a négyzetnél”). Összesen mindezek kombinációjából 48 inger képezhető, melyeket random sorrendben mutattunk be a személyeknek, és arra kértük őket, hogy két perc alatt minél többet oldjanak meg ezekből. Az idő múlását a képernyő közepén futó csík jelezte. A kísérletben mértük a megoldott feladatok számát és a helyes válaszok arányát. 
A következőkben egy ábrát és egy állitást fogsz látni. Döntsd el, hogy az állítás igaz-e az ábrára!

Oldj meg két percen belül minél többet!

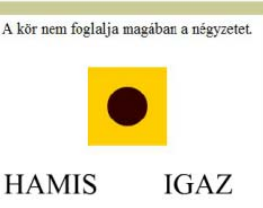

\section{MEHET}

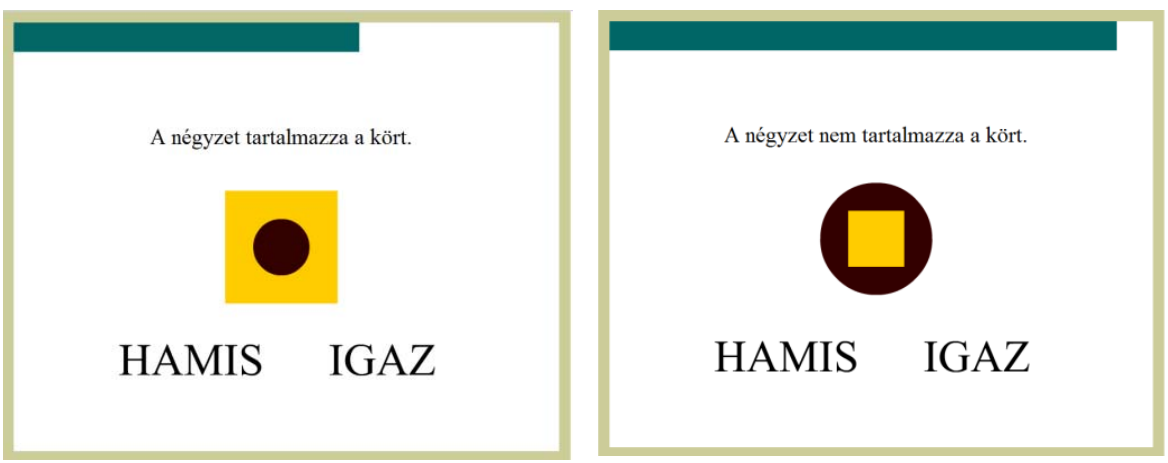

8. ábra. Logikai érvelésfeladat. Példa pozitív és negatív álítást tartalmazó mondatra

2. Verbális próbák:

- Főfogalom alá rendelés (MAWI V. részpróba);

- Fogalomanalógia (Szilágyi, 1990), például cipő - láb = kalap - ........ kabát, orr, láb, fej)

- Számemlékezet (MAWI IV. részpróba);

- Képleírás: Két részletgazdag festményt (Giovanni Antonio Canaletto: A Bucentoro visszatérése Mennybemenetel napján, 1732 és Id. Pieter Bruegel: Betlehemi gyermekgyilkosság, 1566) exponáltunk a vizsgálati személyeknek, és azt az instrukciót kapták, hogy meséljék el a lehető legrészletesebben, mit látnak a képen, mi történik rajta (lásd 9. ábra);

Instrukció: A következőkben két képet fogok mutatni. Kérjük, mondd el, mit látsz ezeken a képeken. Olyan részletesen meséld el, hogy mi van a képen, hogy mi történik, amennyire részletesen csak tudod. 

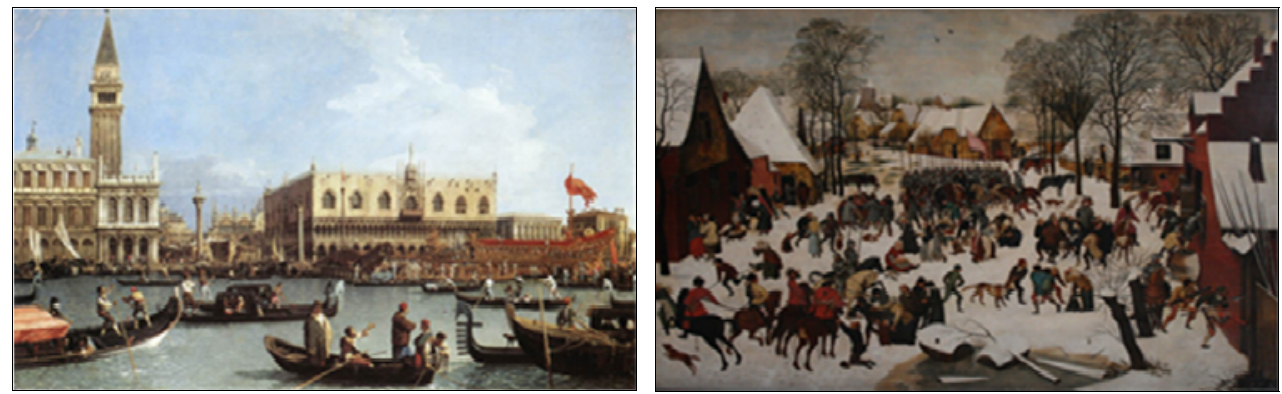

9. ábra. A képleírás-feladathoz használt festmények

A tanulók által a képekről mondott szövegeket hangrögzítôvel felvettük, lejegyeztük, majd a képleírásokat az alábbi szempontok alapján értékeltük:

- A vizsgált személy csupán felsorolja a képen látható dolgokat (1 pont), vagy összefüggő mondatokat használ azok leírására - 2 pont (maximum 2 pont adható).

- A vizsgált személy hány elemét nevezi meg a képnek. (Csupán 1-2 dolgot 1 pont, 3-5 dolgot -2 pont, 6-10 dolgot -3 pont, több mint 10 dolgot 4 pont; maximum 4 pont adható.)

- A vizsgált személy mennyire összetett mondatszerkezeteket használ. (Csupán alanyt és állítmányt tartalmazó mondatokat - 1 pont, egyszerủbb bővített mondatok is elöfordulnak -2 pont, összetett mondatok is megjelennek a szövegben -3 pont, döntően összetett mondatokat használ -4 pont, többszörösen összetett mondatok is megjelennek a szövegben - 5 pont; maximum 5 pont adható.)

- A vizsgált személy összefüggő történetet alkot a képről, vagy csak leírja, hogy mit lát rajta. (Csupán leíró jellegű mondatokat használ - 1 pont, összefüggő történetet alkot, a történet egy cselekményszálon fut -2 pont, összefüggő történetet alkot, a történet 2-3 cselekményszálon fut - 3 pont, összefüggő történetet alkot, a történet cselekménye több mint 3 szálon fut -4 pont, öszszefüggő történetet alkot, a történet sok szálon futó, színes, koherens, kreatív - 5 pont; maximum 5 pont adható.)

- Mennyire választékosan fejezi ki magát a vizsgált személy. (Kevés szót használ, sok a szóismétlés - 1 pont, szinonimákat is használ - 2 pont, választékosan fejezi ki magát -3 pont; maximum 3 pont adható.)

A fenti tesztbattériával az adatfelvételt mindhárom korosztálynál elvégeztük.

3. Az országos kompetenciamérések adatai és a tanulmányi eredmények dokumentumelemzése (a kutatásban részt vevő pedagógusok gyűjtése alapján):

- Matematika és szövegértés-szövegalkotás kompetenciamérések legfrissebb eredményei 
- Hungarofit iskolai testi képességmérés felmérések eredményei: távolugrás, felülések száma megadott időegység alatt, fekvőtámaszok száma megadott időegység alatt, törzsemelések száma megadott időegység alatt, Cooper-futás során megtett távolság megadott időegység alatt, összesített pontszám.

- Matematika, Magyar irodalom, Magyar nyelvtan, Idegen nyelv utolsó félévi eredményei.

- Legutóbbi hivatalos év végi tanulmányi átlag.

\section{VIZSGÁLATI MINTA}

A keresztmetszeti vizsgálatot három, egymástól egyenlő életkori távolságra levő (10 éves, 14 éves és 18 éves) korosztály bevonásával végeztük. A kutatásban 492 fő vett részt. A nemi megoszlás egyenletesnek mondható, 205 fiú és 287 lány került a végleges mintába, egyedül a 18 éveseknél van lány fölény (1. táblázat). Fokozottan ügyeltünk az anonimitásra és az adatok bizalmas kezelésére, így a neveket kódokkal helyettesítettük, és egyedül a kompetenciaadatokat összegyüjtő pedagógusok tudták, hogy melyik kód kihez tartozik, természetesen az erre vonatkozó információkat a vizsgálat befejeztével megsemmisítettük.

A kutatásban a következő iskolák tanulói vettek részt:

- Eszterházy Károly Főiskola Gyakorló Általános Iskola, Eger: 5-8. és 12. évfolyam;

- Felsőtárkányi Általános Iskola, Felsőtárkány: 5. és 8. évfolyam;

- Pásztorvölgyi Általános Iskola és Gimnázium, Eger: 12. évfolyam;

- Balassi Bálint Általános Iskola Tinódi Sebestyén Tagiskolája, Eger: 5. és 8. évfolyam;

- Egri Kereskedelmi, Mezőgazdasági, Vendéglátóipari Szakközép- Szakiskola és Kollégium, Eger: 12. évfolyam.

A vizsgálati minta életkori és nemek szerinti megoszlását az 1. táblázat tartalmazza.

1. táblázat. A minta életkori és nemek szerinti megoszlása

\begin{tabular}{|l|r|r|c|}
\hline \multirow{2}{*}{ Korcsoport } & \multicolumn{2}{|c|}{ N e m } & \multirow{2}{*}{ Összesen } \\
\cline { 2 - 3 } & Fiú & Lány & \\
\hline 10 évesek & 90 & 104 & 194 \\
\hline 14 évesek & 73 & 93 & 166 \\
\hline 18 évesek & 42 & 90 & 132 \\
\hline Összesen & 205 & 287 & 492 \\
\hline
\end{tabular}

Az iskolák tekintetében igyekeztünk kiegyensúlyozni a szocioökonómiai háttérváltozókat, így egri és Eger környéki, különböző profilú intézményeket egyaránt bevontunk a vizsgálatba, valamint a hátrányos helyzetű tanulóktól a jó anyagi háttérrel rendelkező tanulókig igyekeztünk egy kontinuumot vizsgálni. 


\section{VIZSGÁLATI EREDMÉNYEK}

Dorner és munkatársai (jelen kötetben 25-56. oldalon bemutatott) IKT használati szokásokat felmérő kérdőíve alapján a vizsgálati mintát három csoportra osztottuk. A csoportokat (keveset használók, átlagos használók, sokat használók) a következőképpen hoztuk létre: a saját korcsoportban a diákokat a 25\%-os kvadránsig a keveset számítógépező, a 75\%-os kvadránstól a sokat számítógépező csoportba soroltuk. Ezeket a csoportokat az átlagos használók csoportjával (25\% és 75\% közötti számítógépezés) hasonlítottuk össze (2. táblázat).

2. táblázat. A minta számítógép-használati idejének megoszlása

\begin{tabular}{|c|c|c|c|}
\hline \multirow{2}{*}{ Életkor } & Keveset & Átlagos & Sokat \\
\cline { 2 - 4 } & \multicolumn{3}{|c|}{ h a s z n á 1 ó $\mathrm{k}$} \\
\hline 10 év & $<=5,1$ óra/hét & $5,1-11,8$ óra/hét & $>=11,8$ óra/hét \\
\hline 14 év & $<=7,6$ óra/hét & $7,6-19,7$ óra/hét & $>=19,7$ óra/hét \\
\hline 18 év & $<=8,1$ óra/hét & $8,1-20,5$ óra/hét & $>=20,5$ óra/hét \\
\hline
\end{tabular}

A számítógép-használati idő megoszlásából látható, hogy csak a 10 éveseknél találkozunk számottevően rövidebb idejű számítógép-használattal. A két felső korcsoportnál ez a különbség már sokkal kisebb. Mondhatni, a számítógép-használati szokások jellegzetességei az általános iskola végére kialakulnak.

A mutatókat sztenderdizált formában jelenítjük meg, hogy a változókat a különböző mértékegységektől függetlenül a mérőeszközönként vagy változó csoportokként összefogva mutathassuk be. A grafikonokon azonban megfigyelhetőek a nyers pontszámok, valamint a tengelyfeliratokon a teljes minta átlaga az adott mutatóra. A változók grafikonokon szerepeltetett nevei mellett feltüntettük, hogy mely használati csoportok között mutatkoznak szignifikáns különbségek (például a_c ${ }^{* *}$ jelentése: a és c csoport, tehát keveset és sokat használók között $p<0,01$ szignifikanciaszintet elérő különbség mutatkozott. ${ }^{*} p<0,05,{ }^{* * *} p<0,01,{ }^{* * *} \mathrm{p}<0,001$, a kompetencia és tanulmányi eredményeknél $(p<0,001)$. Az eredmények egyszempontos ANOVA-vizsgálatok összesítései, amelyekben a függő változó az adott mutató a vizsgált szempont pedig a korábban definiált kvadránsok szerinti felosztása a mintának keveset, átlagosan és sokat használókra. A szempont szerinti átlagok összehasonlításának szignifikanciaszintjei korrekciók nélkül (LSD) vannak feltüntetve.

\section{Az online pszichológiai tesztek eredményei}

A továbbiakban az online pszichológiai tesztek eredményeit mutatjuk be a kognitív próbák szerinti bontásban. 


\section{Reakcióidő sztenderdizált átlagok}

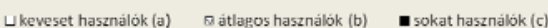

Reakcióido átlagos RI ( $m=456.40)$

Reakcioido legjobb RI $(m=329.50)$

szig. dift: a_b $b^{* *}$

szie. diff.: $a_{-} b^{*}$

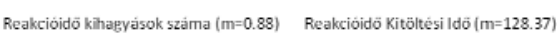

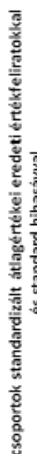
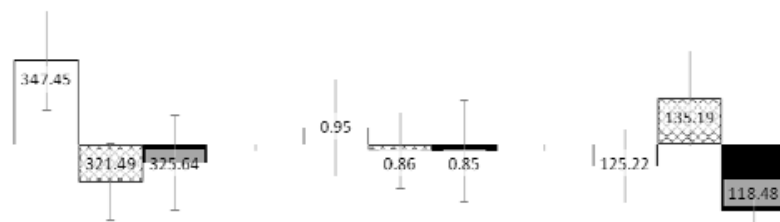

10. ábra. A reakcióidő sztenderdizált különbségei a „keveset” az „átlagos” és a „sokat” használók körében

Mint a 10. ábrán látható, a vizsgált négy mutatóból (átlagos reakcióidő, legjobb reakcióidő, a kihagyások száma, a teljes kitöltési idő) két szignifikáns különbséget kaptunk: a keveset számítógépező tanulók mind az átlagos használó csoportnál, mind a sokat számítógépezőknél hosszabb reakcióidőt mutattak átlagosan, valamint a megfigyelt legjobb reakcióidő is nagyobb volt ebben a csoportban.

Go-NoGo próba

Go-NoGo sztenderdizált átlagok

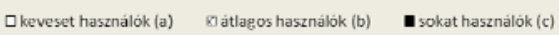

Go-NoGo átlagos RI (helyes) Go-NoGo legiobb RII (helyes)

$(m=589.84) \quad(m=448.45) \quad$ Go-NoGo kihagyajsok száma Go-NoGo hibázások száma Go-NoGo Kitöltési

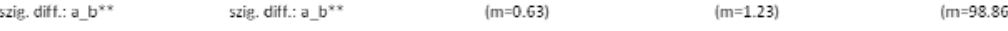

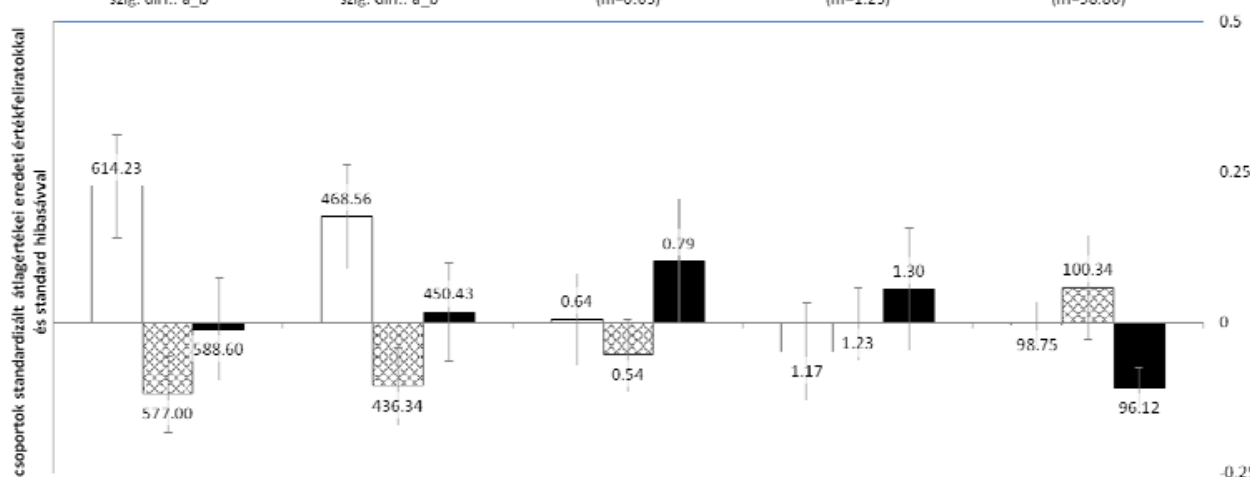

11. ábra. A Go-NoGo sztenderdizált különbségei a „keveset” az „átlagos” és a „sokat” használók körében 
A Go-NoGo vizsgálat a kognitív rendszer gátlási mechanizmusainak gyorsaságát méri. A vizsgált 5 mutatóból (helyes válaszok átlagos reakcióideje, helyes válaszok közül a leggyorsabb reakcióidő, a kihagyások és hibázások száma, kitöltési idő) kettőben találtunk szignifikáns különbséget, a legjobb és az átlagos reakcióidő is gyengébbnek, vagyis nagyobbnak mutatkozott a keveset használó diákoknál, mint a másik két csoportnál (11. ábra).

\section{Számterjedelem}

\section{Számterjedelem sztenderdizált átlagok}
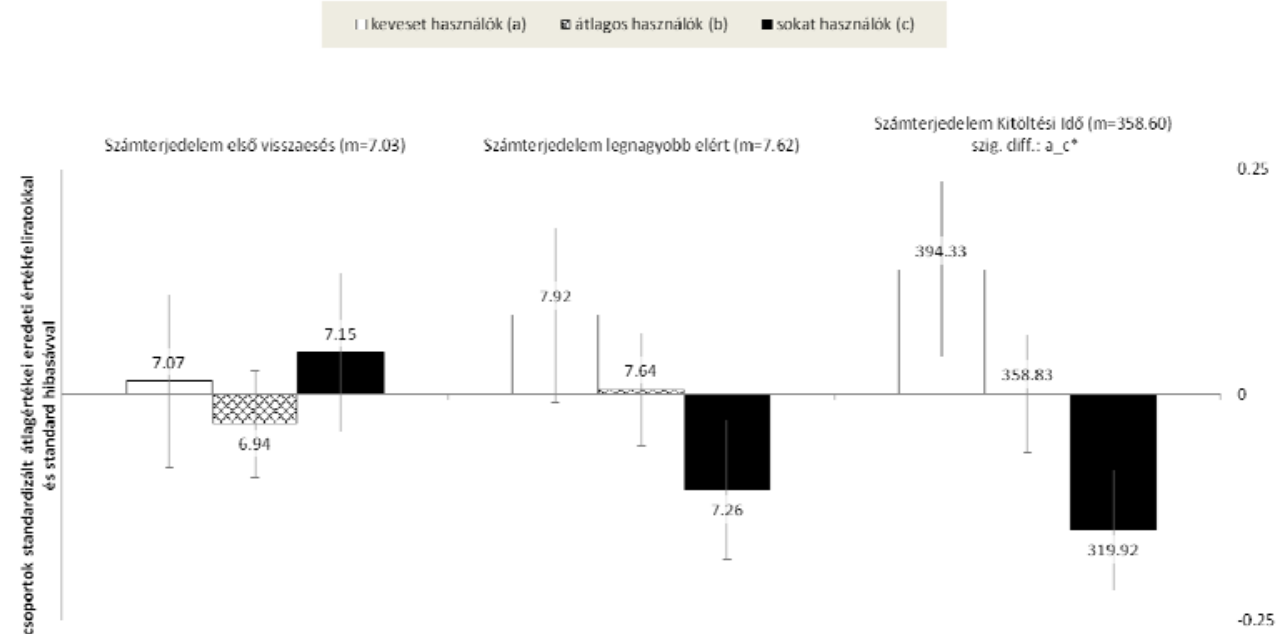

12. ábra. A Számterjedelem sztenderdizált különbségei a „keveset” az „átlagos” és a „sokat” használók körében

Számterjedelem-vizsgálattal a rövid távú memória terjedelmét mértük. Az eredmények értelmezésénél csak az 5 és 9 közötti eredményeket vizsgáltuk, mivel csoportos felvétel során nem volt kizárható, hogy a vizsgálati személyek egy része lejegyezte a számsort. Legalábbis a 12-13-as számterjedelem jelentős mennyiségủ előfordulásából erre következtettünk. A 3 vizsgált változóból csupán egynél találtunk szignifikáns csoportkülönbséget, a számterjedelem-teszt teljes kitöltési idejében szignifikáns különbség mutatkozott a keveset használó diákok javára a sokat használókkal szemben. Hasonló mintázat mutatkozik a legnagyobb elért érték tekintetében, amely a hagyományos számterjedelem-mérés elsődleges mutatója, ugyanakkor az nem szignifikáns. Mivel a számok lejegyzése nem volt ellenőrizve, elképzelhető, hogy a különbségeket a különböző csoportok különböző mértékủ instrukcióhoz való ragaszkodása okozta (12. ábra). 
Téri memória vizsgálat

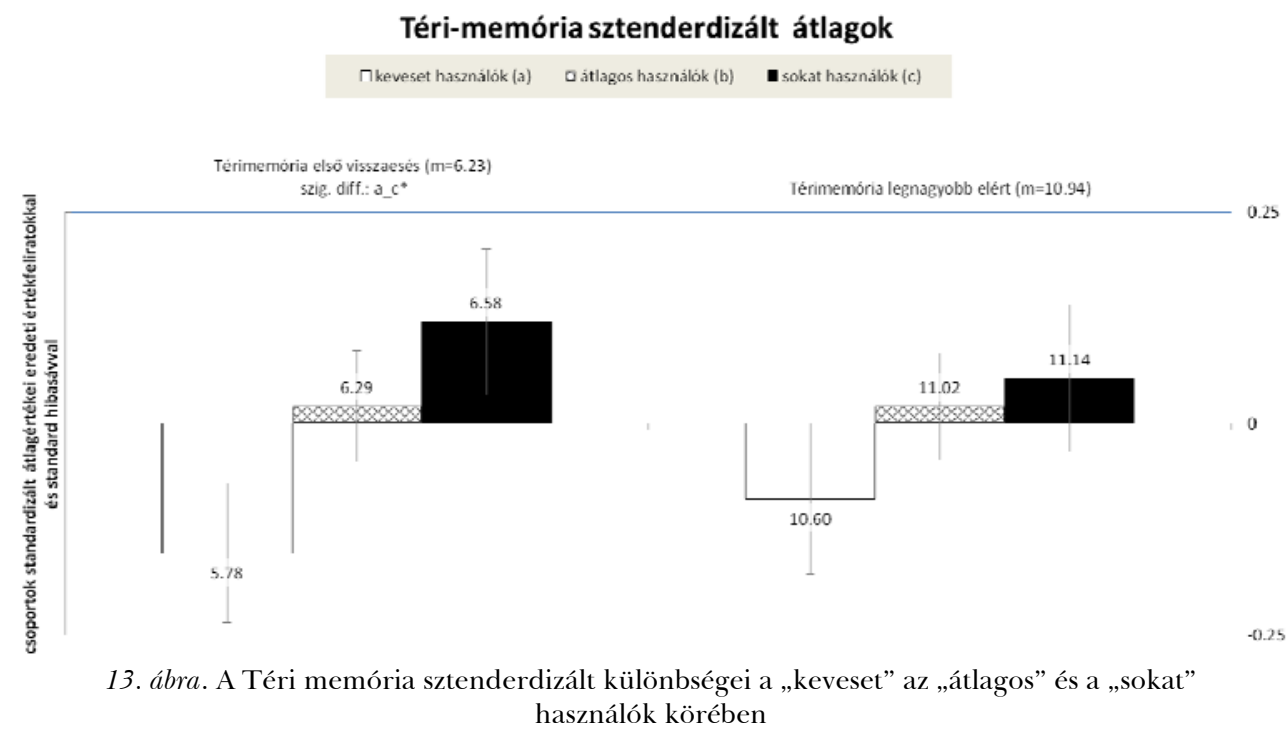

A téri memória vizsgálatakor az első visszaesést és a legnagyobb elért terjedelmet vizsgáltuk. Amint a grafikonból (13. ábra) is látszik, a keveset számítógépezők gyengébb teljesítményt mutattak a sokat számítógépezőkhöz viszonyítva, az első visszaesés mutató alapján, ugyanakkor a végső eredmény nem különbözik szignifikánsan.

Logikai alakpróba

Logikai alakpróba sztenderdizált átlagok

口keveset használók (a) घátlagos használók (b) U sokat használók (c)

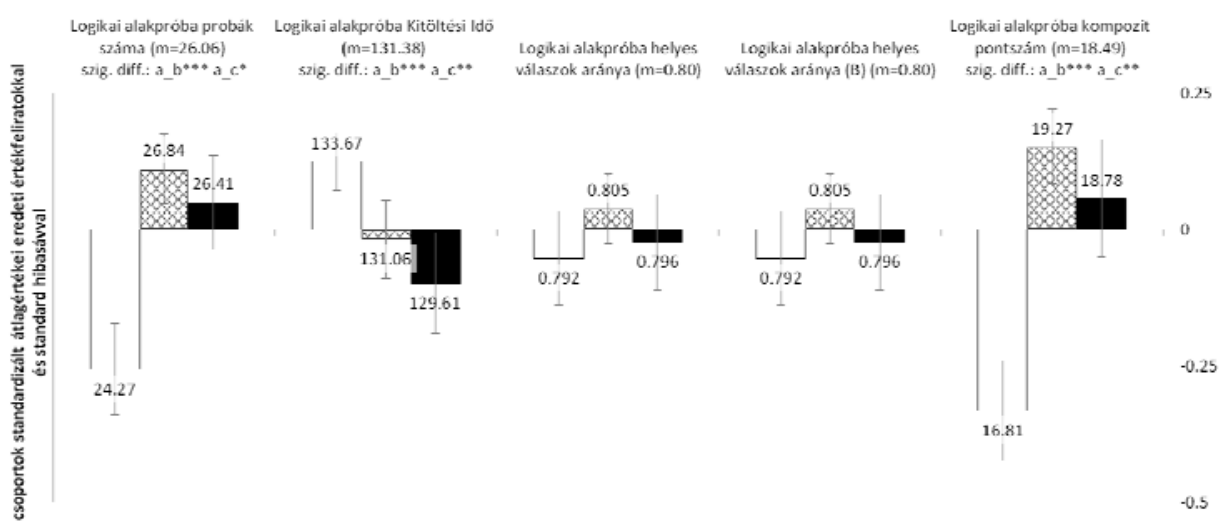

14. ábra. A Logikai alakpróba sztenderdizált különbségei a „keveset” az „átlagos” és a „sokat” használók körében 
A vizsgálat két alak viszonyára kérdez rá, amely egyes esetekben szükségessé teszi a többszörös tagadás állításának igazságvizsgálatát. Az öt mutatóból álló szempontsorban (adott idő alatt megválaszolt kérdések száma, helyes válaszok száma, a helyes válaszok aránya - két árnyalatokban eltérő számítással-, egy a mennyiségből és a sikeres próbák számából generált kompozit pontszám) a teljesített (helyes) próbák számában, a kitöltési időben és a kompozit pontszámban is szignifikánsan gyengébb teljesítményt mutattak a keveset számítógépező gyerekek a másik két csoporthoz képest (14. ábra). Fontos mozzanat, hogy itt a logikai viszonyok értelmezéséhez téri viszonyokat kellett feldolgozni.

Téri forgatás

Téri forgatás sztenderdizált átlagok

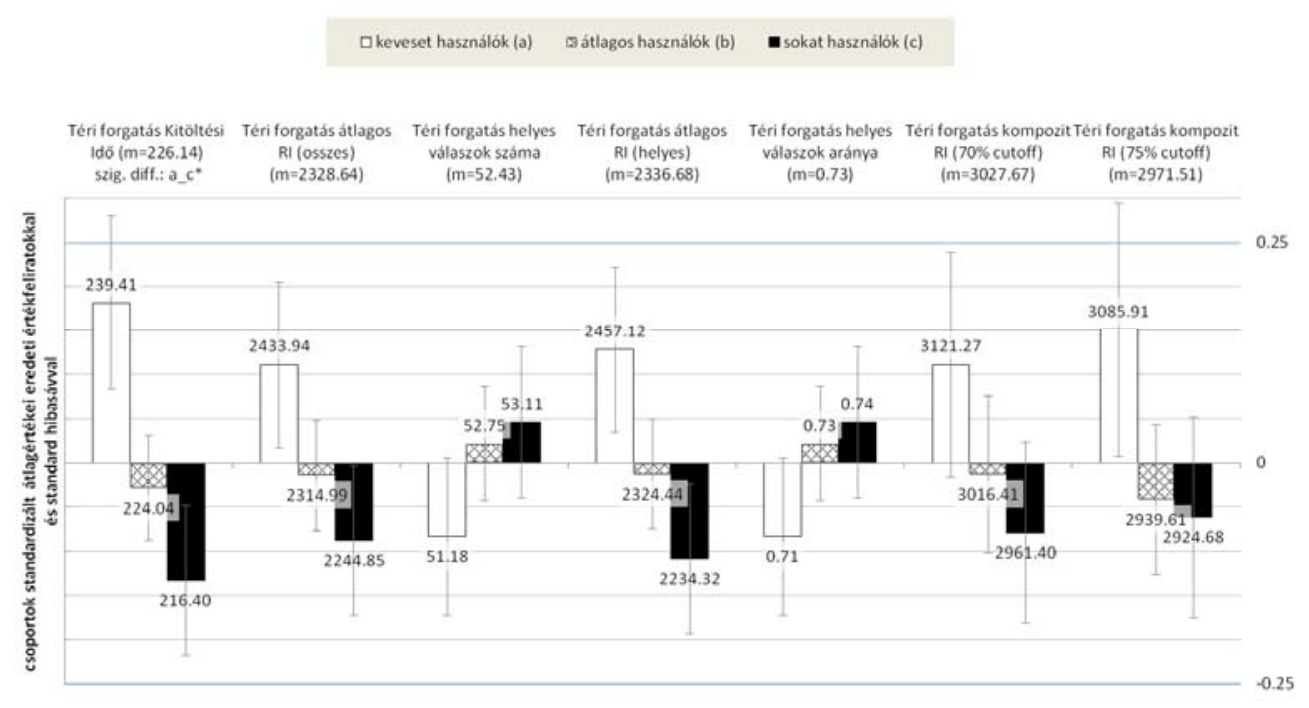

15. ábra. A Téri forgatás sztenderdizált különbségei a „keveset” az „átlagos” és a „sokat” használók körében

A téri forgatás szinte minden gondolkodási művelet részét képezi, azonban a vizsgált mutatók mentén a 3 csoport egyedül a kitöltési idő tekintetében mutatott szignifikáns különbséget, ahol a keveset számítógépezők a teljes tesztbattériát szignifikánsan hosszabb idő alatt töltötték ki, mint a sokat számítógépező társaik (15. ábra). 


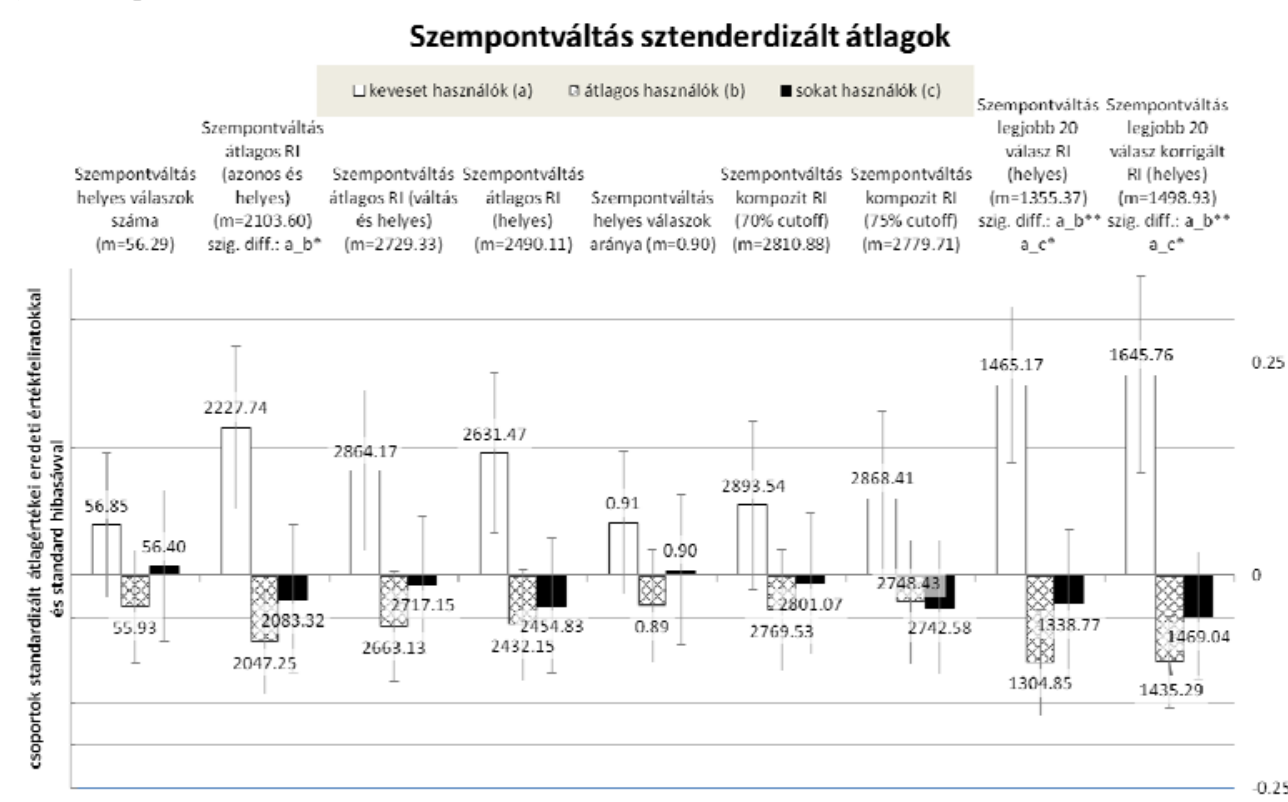

16. ábra. A Szempontváltás sztenderdizált különbségei a „keveset” az „átlagos” és a „sokat” használók körében

A szempontváltás teszt a megosztott figyelem és gátlás kognitív teljesítményét méri. Szignifikáns különbséget a váltás nélküli átlagos reakcióidőben, a legjobb 20 válasz reakcióidejében és legjobb 20 válasz korrigált reakcióideje esetében kaptunk, a keveset használók gyengébb teljesítményt nyújtottak, bár kifejezetten a szempontváltás és a rá következő azonos feladat differenciálásakor ez a reakcióidőkülönbség csak az azonos próbákra adott reakcióidőben volt tetten érhető. A 20 legjobb reakcióidőt mérő mutatókban a keveset számítógépező csoport mind a sokat, mint az átlagos mértékben számítógépező csoporttól leszakadt szignifikáns mértékben (16. ábra). 
Egyszerüsített Stroop-teszt

Egyszerüsített stroop teszt sztenderdizált átlagok

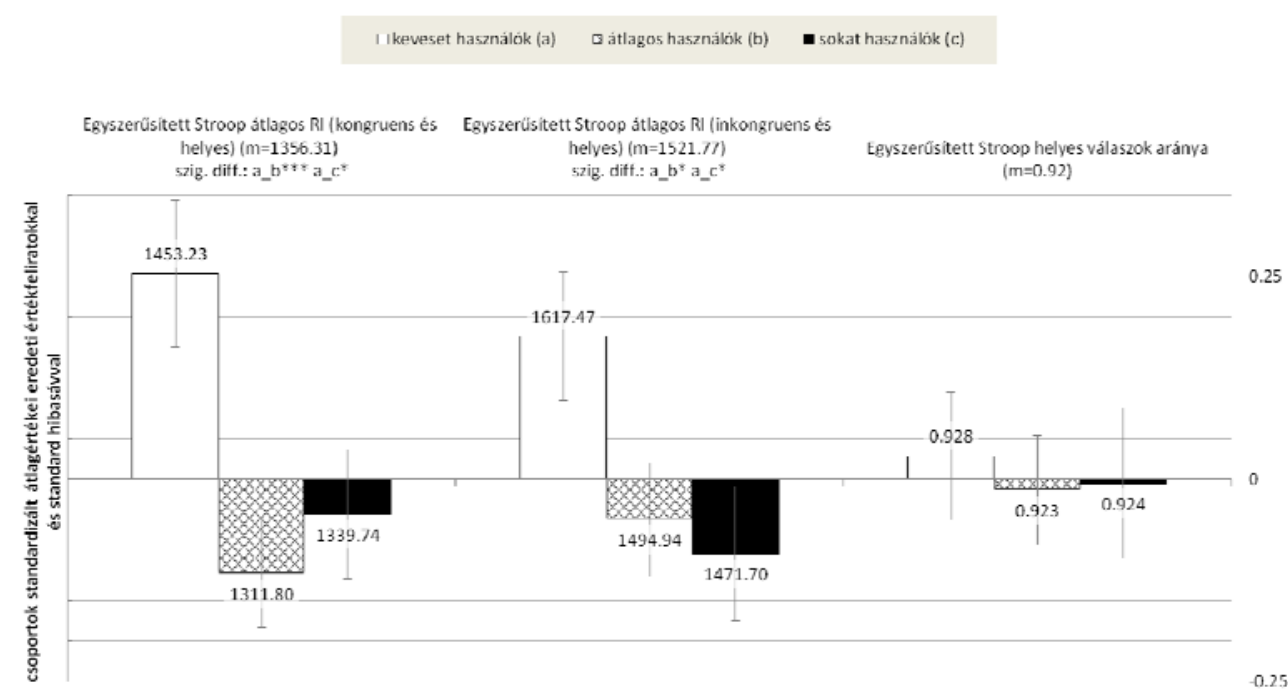

17. ábra. Az Egyszerűsített Stroop-teszt sztenderdizált különbségei a „keveset” az „átlagos” és a „sokat” használók körében

A Stroop-teszt a gátlási funkciókkal áll kapcsolatban. Szignifikáns különbségeket mind a kongruens és helyes, mind az inkongruens és helyes válaszok reakcióidejében is találtunk, a keveset számítógépezők reakcióideje szignifikánsan hosszabb a másik két csoporténál (17. ábra).

A számítógép-használati szokások alapján elkülönülő elemzések mellett az adatok korcsoportok szerinti elemzést is elvégeztük. A korcsoportok szerinti felosztás tulajdonképpen a mutatók validitásvizsgálatának is tekinthető. Joggal feltételezhetjük, hogy a különböző kognitív készségek a fejlődés során javulnak. A korcsoportok szerinti összehasonlításban szinte minden mutatóban szignifikáns különbséget találtunk a különböző életkorú csoportoknál, az elemi pszichés funkciók fejlődése kimutatható volt. A mutatók közötti különbségekből esetenként arra tudtunk következtetni, hogy a különböző készségek milyen korban fejlődnek különösen vagy érnek el egy bizonyos fejlettségi szintet, hogy azután csak kevéssé változzanak. A reakcióidő-vizsgálat mutatói azt jelzik, hogy a reakcióidő elsősorban az első és második korcsoport között javul, mind a legjobb, mind az átlagos reakcióidő tekintetében, miközben a kihagyások száma nem változik a korcsoportok között. A Go-NoGo, mint a gátlást mérő vizsgálat, a reakcióidőhöz hasonló eredményekre vezet, ugyanakkor a reakcióidő-különbségek itt a 2. és 3. korcsoport között is jelentős javuláson mennek át, illetve a hibázások tekintetében kizárólag a legidősebb csoport eredményei javulnak jelentősen. A számterjedelem tekintetében a legnagyobb elért terjedelem és az első visszaesés mutatói egyenletes fejlődést mutatnak 
a korcsoportok között. Az idősebb korcsoportok jobbak a fiatalabbaknál. A téri memória is egyenletes különbségeket jelez, a kor előrehaladtával javul a téri vizuális memória. A logikai alakpróba egyes mutatói szintén elkülönítik a korcsoportokat, míg a próbák száma és helyes válaszok száma inkább a legfiatalabb csoport elmaradását emeli ki, addig a helyes válaszok aránya mutatók inkább a legidősebb csoport előnyét. A csoportok közötti különbség minden korcsoport viszonylatában a várt irányú és jelentős. A kor előrehaladtával a logikai érvelés pontossága és gyorsasága növekszik. A téri forgatás esetében a kitöltési idő és átlagos reakcióidőben a korcsportok a fejlődéstől független sorrendben vannak, a legfiatalabb csoport a leggyorsabb. Ez a rendhagyó sorrend akkor is megmarad, amikor csupán a helyes választások reakcióidejét vizsgáljuk. A helyes válaszok száma és aránya azonban már a kognitív készségek érésének megfelelő sorrendben különül el, és a hibázások és gyorsaság hatásait kombináló kompozit pontszám is ezt tükrözi. A kor előrehaladtával tehát javul a téri forgatás készsége is. A szempontváltás mutatói szinte minden esetben tükrözik a javuló figyelemirányítási, -váltási készségeket, elsősorban azonban a legfiatalabb csoport gyengébb reakcióideje különül el. A középső korcsoport szintén gyorsabbnak látszik, mint az idősebbek, a legjobb reakcióidők és az átlagos reakcióidő tekintetében. A helyes válaszok számában a középső csoport mindkét csoportnál gyengébb eredményeket mutat, tehát a középső korcsoport kevésbé szelektív a helytelen ingerekre, amely magyarázatként szolgálhat a gyorsabb reakcióidőkre. A kompozit pontszámok már jól diszkriminálnak a korcsoportok között, ugyan a középső és legidősebb korcsoport közötti különbség nem szignifikáns. A korcsoportok átlagait és szórásait a terjedelmi korlátok miatt itt nem közöljük, de a kutatócsoportnál megtalálhatók, az online tesztbattériával együtt.

\section{A verbális próbák eredményei}

Az online pszichológiai tesztek csoportos adatfelvétele mellett a verbális próbák egyéni vizsgálatban történtek. A képleírás feladatában hangrögzítést is alkalmaztunk, amely sajnos jelentős adatvesztést eredményezett. A verbális próbák statisztikai elemzését ezért csak kisebb mintán tudtuk elvégezni (3. táblázat).

3. táblázat. Vizsgálati minta eloszlása a verbális próbáknál csoportonként

\begin{tabular}{|l|c|c|c|c|}
\hline & $\begin{array}{c}\text { Főfogalom } \\
(\mathrm{N})\end{array}$ & $\begin{array}{c}\text { Fogalomanalógia } \\
(\mathrm{N})\end{array}$ & $\begin{array}{c}\text { Számemlékezet } \\
(\mathrm{N})\end{array}$ & $\begin{array}{c}\text { Képleírás } \\
(\mathrm{N})\end{array}$ \\
\hline Keveset & 110 & 111 & 111 & 85 \\
\hline Átlagos & 155 & 155 & 154 & 118 \\
\hline Sokat használók & 90 & 92 & 91 & 68 \\
\cline { 2 - 5 } & 355 & 358 & 356 & 271 \\
\hline \multicolumn{2}{|c|}{ Ö s s z e s e n } & &
\end{tabular}


A verbális feladatok közül a főfogalom, a fogalomanalógia és a számemlékezet terén nem találtunk különbséget a számítógép-használati csoportok között (4. táblázat).

4. táblázat. A verbális részpróbák eredményei: főfogalom, fogalomanalógia, számemlékezet

\begin{tabular}{|c|c|c|c|c|}
\hline & & $\begin{array}{l}\text { Főfogalom } \\
\text { (átlag) }\end{array}$ & $\begin{array}{l}\text { Fogalomanalógia } \\
\text { (átlag) }\end{array}$ & $\begin{array}{l}\text { Számemlékezet } \\
\text { (átlag) }\end{array}$ \\
\hline Keveset & \multirow{3}{*}{ használók } & 14,25 & 3,27 & 10,81 \\
\hline Átlagos & & 14,18 & 3,55 & 10,66 \\
\hline Sokat & & 14,9 & 3,43 & 10,45 \\
\hline \multicolumn{2}{|c|}{$\begin{array}{l}\text { Többváltozós } \\
\text { varianciaanalízis }\end{array}$} & $\begin{array}{c}\mathrm{F}_{(352)}=0,91, \\
p=0,913\end{array}$ & $\begin{array}{c}\mathrm{F}_{(355)}=2,26 \\
p=0,106\end{array}$ & $\begin{array}{c}\mathrm{F}_{(353)}=0,886 \\
p=0,413\end{array}$ \\
\hline
\end{tabular}

A negyedik verbális részpróbánál azonban a szóbeli kifejezőkészségnél, az összefüggő történetmesélésénél már szignifikánsan jobb eredményt mutatnak a keveset számítógépező fiatalok. Az önálló szövegalkotásra, a képleírásra kapott összpontszámuk is szignifikánsan magasabb, mint az átlagos mértékben vagy sokat számítógépező társaiké (5. táblázat).

5. táblázat. A verbális részpróbák eredményei: a képleírás adatai

\begin{tabular}{|c|c|c|c|c|c|c|c|}
\hline & & $\begin{array}{c}\text { Felsorolás/ } \\
\text { összefüggő } \\
\text { mondatok }\end{array}$ & $\begin{array}{l}\text { Hány dol- } \\
\text { got nevez } \\
\text { meg a ké- } \\
\text { pen? }\end{array}$ & \begin{tabular}{|c|} 
A mondat- \\
szerkezet \\
összetett- \\
sége
\end{tabular} & $\begin{array}{c}\text { Leíró jelleg/ } \\
\text { összefüggő } \\
\text { történet }\end{array}$ & $\begin{array}{l}\text { Választé- } \\
\text { kosság }\end{array}$ & $\begin{array}{c}\text { Össz- } \\
\text { pontszám }\end{array}$ \\
\hline Keveset & \multirow{3}{*}{ 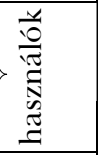 } & 3,9294 & 5,3765 & 4,9059 & 2,7412 & 3,3059 & 24,67 \\
\hline Átlagos & & 3,8390 & 5,2542 & 4,8898 & 2,5169 & 3,2627 & 24,22 \\
\hline Sokat & & 3,7353 & 4,9118 & 4,4412 & 2,5147 & 2,9853 & 22,76 \\
\hline \multicolumn{2}{|c|}{$\begin{array}{l}\text { Többváltozós } \\
\text { varianciaanalízis }\end{array}$} & $\begin{array}{c}\mathrm{F}_{(268)}=2,86, \\
p=0,059\end{array}$ & $\begin{array}{c}\mathrm{F}_{(268)}=2,452, \\
p=0,088\end{array}$ & $\begin{array}{c}\mathrm{F}_{(268)}=2,471, \\
p=0,086\end{array}$ & $\begin{array}{c}F_{(268)}=4,269 \\
p=0,015\end{array}$ & $\begin{array}{c}\mathrm{F}_{(268)}=1,17 \\
p=0,312\end{array}$ & $\begin{array}{c}F_{(268)}=4,1 \\
p=0,018\end{array}$ \\
\hline
\end{tabular}

Két ok miatt figyelemfelhívó ez az eredmény: egyrészt azért, mert a többi képességvizsgálatnál konzekvensen az átlagos mértékű számítógép-használók értek el jobb eredményeket. Másrészt azért, mert az online tesztfeladatok közül a számemlékezet-próbában is (amely a munkamemória verbális területét méri) szignifikáns csoportkülönbséget találtunk a számterjedelem-teszt teljes kitöltési idejében a keveset használó diákok javára a sokat használókkal szemben. Hasonló mintázat mutatkozik a legnagyobb elért érték tekintetében, amely a hagyományos számterjedelem-mérés elsődleges mutatója, de nem szignifikáns mértékben. Óvatosságra int 
ugyanakkor az eredmények értelmezésében az az adat is, hogy a szövegértés kompetenciamérési értékpontjai az átlagos használók és a sokat használók esetében magasabbak.

\section{A KOMPETENCIAMÉRÉSEK, A HUNGAROFIT VIZSGÁLATOK ÉS A TANULMÁNYI EREDMÉNYEK ÖSSZEHASONLÍTÁSA A „KEVESET” ÉS „SOKAT” HASZNÁLÓK KÖRÉBEN}

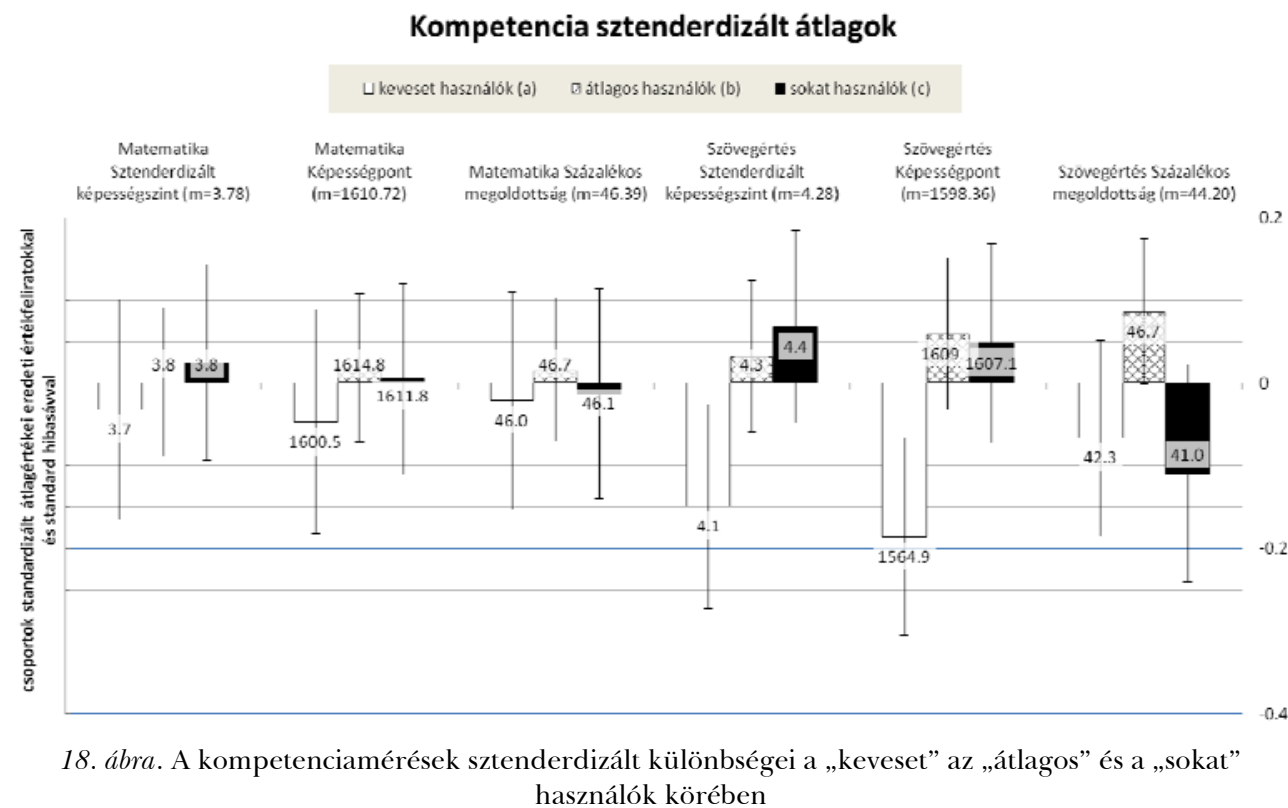

A kompetenciafelmérések matematika és szövegértés pontszámokat tartalmaznak, amelyekben szignifikáns különbség nem mutatkozott a három csoport között, jóllehet a szövegértés százalékos megoldottságot leszámítva a keveset számítógépezők átlagértékei szisztematikusan alacsonyabbak, ahogyan azt a 18. ábrán láthatjuk. 


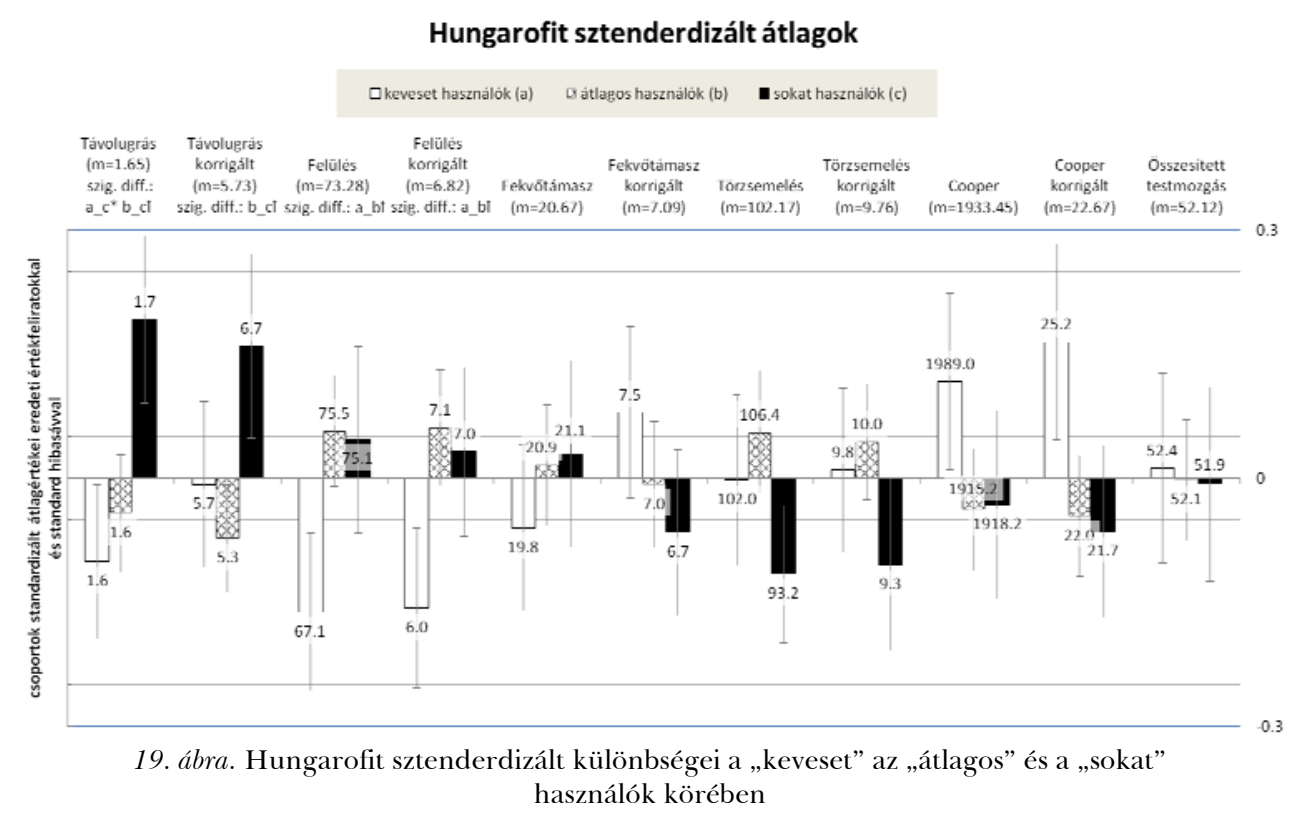

A Hungarofit vizsgálatok különböző nagymozgásos teljesítményeket mérnek. A 19. ábrán látható, hogy a sokat számítógépezők távolugrásban szignifikánsan jobbak a keveset használó csoportnál és tendenciózusan az átlagos használati csoportnál. Bár nincs szignifikáns különbség, de tendenciájában a felülésben a keveset számítógépezők gyengébbek, mint az átlagos használó csoport.

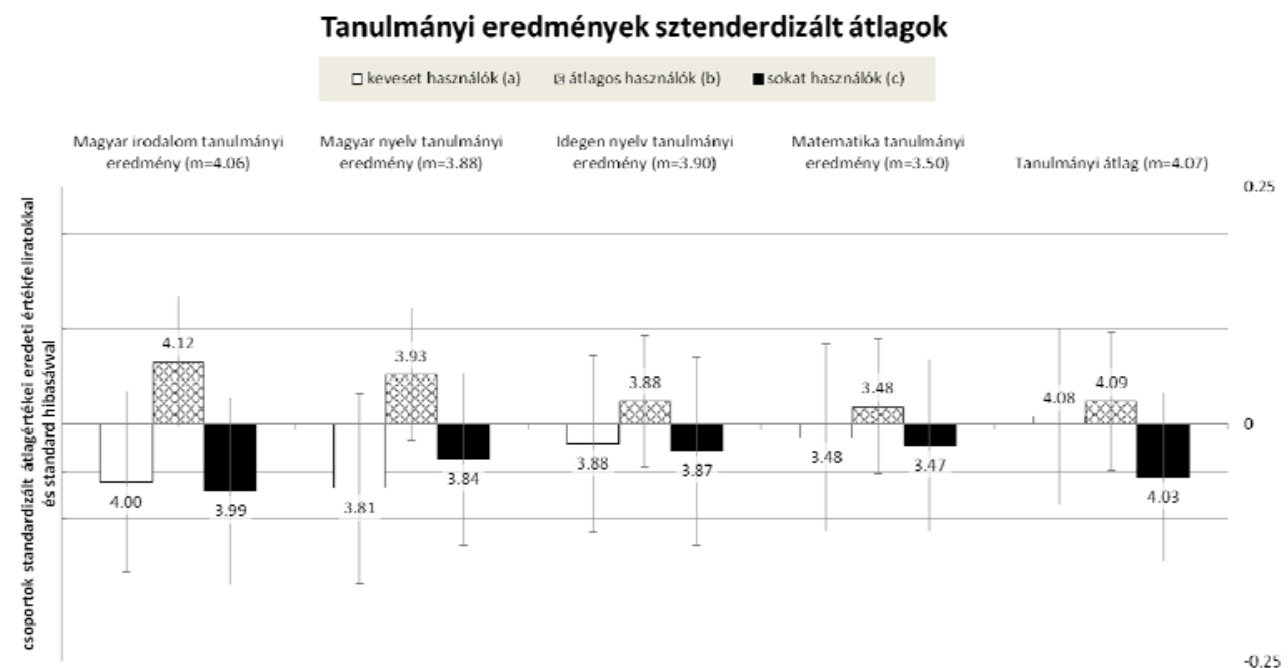

20. ábra. A tanulmányi eredmények sztenderdizált különbségei a „keveset” az „átlagos” és a „sokat” használók körében 
A magyar nyelv és irodalom, idegen nyelv, matematika tanulmányi eredmény és az összesített tanulmányi átlag tekintetében nem mutatkozott szignifikáns különbség a különböző csoportok között (20. ábra).

\section{DISZKUSSZIÓ}

Hipotézisünk volt, hogy a gyakori IKT-használat bizonyos készségek javulását (például vizuális észlelési képességek), míg más készségek romlását (például motorikus, verbális képességek) eredményezi, és hogy a képességbeli különbségek a tanulmányi teljesítményekben is megmutatkoznak.

Ezzel kapcsolatosan főbb eredményeink a következőek:

1. A keveset számitógépező tanulók mind az átlagos csoportnál, mind a sokat számítógépezőknél hosszabb reakcióidőt mutattak a különböző feladatokban.

2. A téri memória vizsgálatakor a keveset számitógépezók gyengébb teljesitményt mutattak a másik két csoporthoz viszonyítva. A logikai alakpróbában is a keveset számítógépező gyerekek mutattak gyengébb teljesítményt.

3. A verbális próbák eredményei csak néhány részterületen jeleznek szignifikánsan jobb teljesítményeket a ritkán számítógépező csoport javára.

4. A kompetenciaméréseknél és a tanulmányi eredményben nem voltak szignifikáns különbségek a különböző korcsoportok között. Ugyanígy a Hungarofit eredmények sem jelezték a motorikus képességek különbségeit.

Mindezek alapján elmondhatjuk, hogy hipotézisünk csak részben igazolódott. A kutatás eredményei azt mutatják, hogy a gyakoribb számítógép-használat a reakcióidővel szignifikáns pozitív összefüggést mutat minden korcsoportban, szinte minden feladatban, vagyis a gyakori számítógép-használat gyorsuló reakcióidőkhöz vezethet, azonban az okságra vonatkozóan csak longitudinális vizsgálat alkalmazásával vonhatnánk le következtetéseket.

A mért képességterületeken azt tapasztaltuk, hogy bár nem szignifikáns különbséggel, de tendenciaszinten statisztikailag is igazolható, hogy a ritka és az átlagos mértékű számítógép használat egyes tanulói képességekkel pozitív összefüggést mutat (vizuális figyelem), fontos lenne a két tényező viszonyát mélyrehatóbban megismernünk.

\section{KÖVETKEZTETÉSEK}

Megállapíthatjuk, hogy az eszközhasználat kognitív készségekre gyakorolt hatása az iskolai teljesítmény eltéréseiben nem manifesztálódik. Feltételezhetjük, hogy azok a képességterületek, amelyekre a gyakoribb vagy a kevesebb IKT-használat hat, nem befolyásolják döntően az iskolai teljesítményt. 
A kutatás eredményei azt mutatják, hogy a gyakoribb számítógép-használat szinte minden feladatban gyorsuló reakcióidőkhöz vezethet. Ezt a szignifikáns pozitív összefüggést minden korcsoportban tapasztaltuk. A mért képességterületeken tendenciaszinten statisztikailag is igazolható, hogy a ritka és az átlagos mértékủ számítógép-használat egyes tanulói képességekkel pozitív összefüggést mutat, több képességvizsgálatnál konzekvensen az átlagos mértékű számítógép-használók értek el jobb eredményeket.

Vizsgálataink alapján csupán az önálló fogalmazásban, történetmesélésben megjelenő verbális képesség az a területet, ahol az IKT-eszközöket keveset használók szignifikánsan jobb eredményt mutattak. Kérdés, hogy ez azért van így, mert nincs is ilyen terület, vagy a mérésünket ki kellene terjeszteni kevésbé mechanikusan mérhető területekre is, gondolunk itt a szövegértés, szókincs stb. vizsgálatára.

A vizsgálatunk legfőbb korlátai és fejlődési irányai az alábbi tényezőkkel kapcsolatosak:

1. Keresztmetszeti elrendezés révén inkább egy jelenlegi állapotról, mintsem oksági viszonyokról vagy fejlődési folyamatról kaphatunk csupán képet.

2. Vizsgálatunkat demográfiai szempontból is érdemes lenne kiterjeszteni: részint egy több településre, esetleg az egész országra kiterjedő reprezentatív mintára.

3. Érdemes lenne a kognitív képességeket mérő feladatokat kiegészíteni egyéb feladatokkal is.

4. Ezenkívül néhány év múlva a jelenlegi tanulók bevonásával longitudinálissá tervezzük alakítani a vizsgálatot, mivel az IKT-eszközök használatának pszichikus sajátosságokra gyakorolt hatásáról hosszú távú vizsgálatokkal még alaposabb, mélyebben beágyazott adatokat nyerhetünk, mint a jelenlegi keresztmetszeti vizsgálatokkal.

\section{IRODALOM}

Alexander, L. M., \& Currie, C. (2004). Young people's computer use: Implications for health educations. Health Education, 4, 254-261.

Bavelier, D., Green, C. S., Schrater, P., \& Pouget, A. (2012). Brain plasticity through the life span: Learning to learn and action video games. Annual Reviews of Neuroscience, 35, 391-416.

Bonnet, M. H., Berry, R. B., \& Arand, D. L. (1991). Metabolism during normal, fragmented, and recovery sleep. Journal of Applied Physiology, 71, 1112-1118.

Boronkai D. (2011). Az internet pszichológiája. Pécsi Tudományegyetem. http://igyk.pte.hu/files/tiny_mce/File/kari_projektek/informaciotudaservenyesules/tanan yagok/1_alprojekt/TM/04_Internetpszichologia.pdf (a hozzáférés dátuma: 2014.12.10.)

Cacioppo, J. T., \& Petty, R. E. (1982). The need for cognition. Journal of Personality and Social Psychology, 42, 116-131.

Dahl, R. E. (1996). The impact of inadequate sleep on children's daytime cognitive function. Pediatric Neurology, 3, 44-50. 
Dahl, R. E. (1998). The consequences of insufficient sleep for adolescents. Links between sleep and emotional regulation. Phi Delta Kappan, 80, 354-359.

Dávid M., Estefánné Varga M., Hatvani A., Taskó T., Dorner L. és Soltész P. (2014). Az IKT-használat hatásai a pszichikus sajátosságokra, vizsgálat a tanulók körében. Kutatási zárótanulmány. Eger: Eszterházy Károly Főiskola.

Demetrovics Zs. és Koronczay B. (2010). Az internetfüggőség néhány pszichológiai vonatkozása. In Talyigás J. (szerk.), Az internet a kockázatok és mellékhatások tekintetében (pp. 121-132). Budapest: Scolar Kiadó.

Dorner L., Hatvani A., Taskó T., Soltész P., Estefánné Varga M. és Dávid M. (2016). IKThasználat 10-18 éveseknél - Egy IKT-eszközhasználati kérdőív bemutatása. Magyar Pszichológiai Szemle, 71(1), 25-56.

Eppright, T., Allwood, M., Stern, B., \& Theiss, T. (1999). Internet addiction: A new type of addiction? Missouri Medical, 96, 133-136.

Greenfield, P. M. (1998). The cultural evolution of IQ. In U. Neisser (Ed.), The rising curve: Long-term gains in IQ and related measures (pp. 81-123). Washington, DC: American Psychological Association.

Greenfield, S. (2009). Identitás a XXI. században. Budapest: HVG könyvek.

Hakala, P. T., Rimpelä, A. H., Saarni, L. A., \& Salminen, J. J. (2006). Frequent computerrelated activities increase the risk of neck-shoulder and low back pain in adolescents. The European Journal of Public Health, 16(5), 536-541.

Hakkarainen, K., Ilomäki, L., Lipponen, L., Muukkonen, H., Rahikainen, M., Tuominen, T. \& Lehtinen, E. (2000). Students' skills and practices of using ICT: Results of a national assessment in Finland. Computers \& Education, 34(2), 103-117.

Jacobs, K., \& Baker, N. A. (2001). The association between children's computer use and musculoskeletal discomfort. Work (Reading, Mass.), 18(3), 221-226.

Kaltiala-Heino, R., Lintonen, T., \& Rimpela, A. (2004). Internet Addiction? Potentially problematic use of the Internet in a population of 12-18-year-old adolescents. Addiction Research and Theory, 12, 89-96.

Kautiainen, S., Koivusilta, L., Lintonen, T., Virtanen, S. M., \& Rimpelä, A. (2005). Use of information and communication technology and prevalence of overweight and obesity among adolescents. International Journal of Obesity, 29(8), 925-933.

Kovács K. (2007). A modern technológia szerepe az IQ generációk közti növekedésében. Világosság, 9.

http://www.vilagossag.hu/pdf/20071109200948.pdf (letöltés dátuma: 2014. november 2.)

Mannir, R., Ratti, M. T., Marchioni, E., Castelnovo, G., Murelli, R., Sartori, I. \& Tartara, A. (1997). Poor sleep in adolescents: A study of 869 17-year-old Italian secondary school students. Journal of Sleep Research, 6(1), 44-49.

Maynard, A. E., Subrahmanyam, K., \& Greenfield, P. M. (2005). Technology and the Development of intelligence: From the loom to the computer. In R. J. Sternberg and D. Preiss (Eds.), Intelligence and Technology: The impact of tools on the nature and development of human abilities (pp. 29-53). Mahwah, NJ: Lawrence Erlbaum Associates.

Molnár Gy. (2011). Az információs-kommunikációs technológiák hatása a tanulásra és oktatásra. Magyar Tudomány, 2011(9), 1038-1047.

Nagy J. (2000). XXI. század és nevelés. Budapest: Osiris Kiadó.

OECD (2015). Students, computers and learning: Making the Connection. PISA, OECD Publishing. 
Pilcher, J. J., \& Walters, A. S. (1997). How sleep deprivation affects psychological variables related to college students' cognitive performance. Journal of American College Health, 46(3), 121-126.

Pléh Cs. (2011). A webvilág kognitív következményei, avagy fényesít vagy butít-e az internet. Korunk, 22(8).

2011. augusztus. http://korunk.org/letoltlapok/Z_ZMKorunk2011augusztus.pdf. (a hozzáférés dátuma: 2014.10.10.)

Prensky, M. (2001). Digitális bennszülöttek, digitális bevándorlók. On the Horizon (NCB University Press), 9(5),

URL: http://goliat.eik.bme.hu/ emese/gtk-mo/didaktika/digital_kids.pdf (a hozzáférés dátuma: 2014.03.15.)

Punamäki, R. L., Wallenius, M., Nygård, C. H., Saarni, L., \& Rimpelä, A. (2007). Use of information and communication technology (ICT) and perceived health in adolescence: The role of sleeping habits and waking-time tiredness. Journal of Adolescence, 30(4), 569-585.

Samari, E., \& Atashak, M. (2011). The effect of learning by ICT on Educational Advances among the Students of payam-e Noor University (PNU). Social and Behavioral Sciences, 29, 464-468.

Sharifi, A., Imani, M. N., \& Eslamieh, F. (2012). Investigation the Role of Information and Communication Technologies on Student's Collaborative Learning. Social and Behavioral Sciences, 55, 1060-1068.

Spear, L. P. (2000). The adolescent brain and age-related behavioral manifestations. Neuroscience and Biobehavioral Reviews, 24, 417-463.

Spiegel, K., Leproult, R., \& Van Cauter, E. (1999). Impact of sleep debt on metabolic and endocrine function. The Lancet, 354 (9188), 1435-1439.

Subrahmanyam, K., Greenfield, P., \& Kraut, R. (2001). The impact of computer use on childrens' and adolescents' development. Applied Developmental Psychology, 22, 7-30.

Szabó É. (2014). A „csók anyutól” a Skype üzenetig. Konferencia-előadás, A pszichológia napja, SZTE Pszichológiai Intézet, 2014.02.21.

Székely L. (2014). Média multitasking. Az új generációk megváltozó médiafogyasztási és kommunikációs szokásairól. Doktori értekezés, Budapesti Corvinus Egyetem, Szociológia Doktori Iskola.

Szilágyi K. (1990). Gondolkodásvizsgáló tesztkészlet. Budapest: kiadó nélkül.

Tamir, D. I., \& Mitchell, J. P. (2012). Disclosing information about the self is intrinsically rewarding. Proceedings of the National Academy of Sciences, 109(21), 8038-8043.

Tari A. (2011). Z generáció. Klinikai pszichológiai jelenségek és társadalom-lélektani szempontok az Információs Korban. Budapest: Tercium.

Vebra, R. (2002). Technology, Innovation, and Education Change: A Global Perspective. 


\title{
ICT EFFECTS ON COGNITIVE FUNCTION IN SCHOOL AGE
}

\author{
DÁVID, MÁRIA - DORNER, LÁSZLÓ - HATVANI, ANDREA - SOLTÉSZ, PÉTER - \\ TASKÓ, TÜNDE - SOLTÉSZ-VÁRHELYI, KLÁRA
}

Background and Aims: In our study we aimed to investigate how the cognitive performance of Hungarian students between 10-18 years changes as a function of ICT usage. We hypothesized that certain skills develop (e.g. visual attention), while others deteriorate (e.g. verbal and motoric skills) as a consequence of extended ICT usage.

Methods and Sample: In a cross-sectional study design that ended in February 2015 cognitive skills in 3 age groups (10, 14 and 18 year olds) with 492 participants (194, 166, and 132 Ss respectively) were measured. The study was performed in primary and high schools of Eger and its surrounding villages. In each age cohort, low, medium, and high ICT usage subgroups were differentiated. A battery of adopted WEB based cognitive tests was used, alongside with national basic competency (mathematical and reading comprehension) and motoric skill and fitness measures (Hungarofit).

Results: We found positive correlations between frequent ICT usage and faster reaction time in every age group. Infrequent ICT use shows positive correlation with several cognitive skills. The competence measures neither in the mathematical-logical and reading comprehension, nor in the Hungarofit motoric skill measure points did not show significant differences among the 3 groups. The most recent student grades of Hungarian literature and grammar, foreign language and maths and also the grade point average did not show significant difference among the age groups.

Conclusions: Medium level ICT usage shows mild positive correlations with cognitive skills, however, this tendency is not manifested in academic performance, competence and motoric skill measures.

Key words: ICT, cognitive skills, Hungarofit, competence measures 